\title{
GUIA DE BOAS PRÁTICAS NAS PME - SOCIEDADES POR QUOTAS
}

\author{
Jorge M. Coutinho de Abreu \\ Alexandre Soveral Martins \\ Carolina Cunha \\ Rui Pereira Dias
}

\section{BEST PRACTICE GUIDE FOR SMES}

- PRIVATE LIMITED LIABILITY COMPANIES 



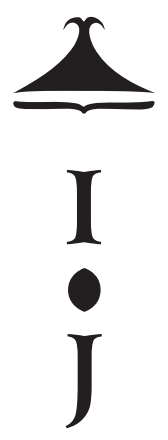


Área de InVESTIGAÇĀo

"As PME: Promoção da Inovação, Crescimento e Competitividade"

Título:

Guia de Boas Práticas nas PME - Sociedades por Quotas

Best Practice Guide for SMES - Private Limited Liability Companies

Autor:

Jorge M. Coutinho de Abreu

CO-AUTOR(ES):

Alexandre Soveral Martins, Carolina Cunha, Rui Pereira Dias

EDIÇÃo

Instituto Jurídico

Faculdade de Direito da Universidade de Coimbra

CONCEPÇÃo GRÁFICA

Frases Favoritas

ISBN

978-989-9075-10-8

DOI:

https://doi.org/10.47907/guia2021_1

\section{Contactos}

geral@ij.uc.pt

www.uc.pt/fduc/ij

Pátio da Universidade | 3004-528 Coimbra 


\title{
GUIA DE BOAS PRÁTICAS NAS PME - SOCIEDADES POR QUOTAS
}

\author{
Jorge M. Coutinho de Abreu \\ Alexandre Soveral Martins \\ Carolina Cunha \\ Rui Pereira Dias
}

\section{BEST PRACTICE GUIDE FOR SMES \\ - PRIVATE LIMITED LIABILITY COMPANIES}

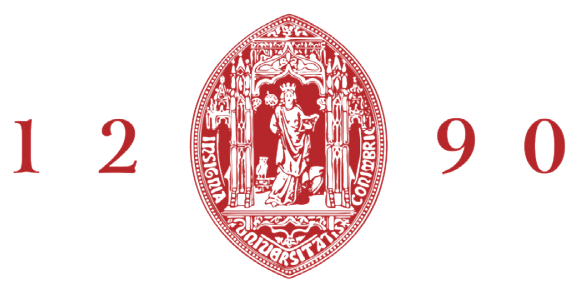

INSTITVTO IIVRIDICO

FACULDADE DE DIREITO

UNIVERSIDADE B

COIMBRA 



\section{ÍNDICE / CONTENTS}

Preâmbulo

Preamble.

I - DA CONSTITUIÇÃO E FINANCIAMENTO

INCORPORATION AND FINANCING

1. Formação

Formation.

2. Financiamento

Financing....

\section{II - DOS SÓCIOS}

SHAREHOLDERS

1. Deliberaçóes dos sócios

Shareholders' decisions

2. Transmissão de quotas

Transfer of shares (quotas)

2.1. Transmissão de quotas entre vivos

Transfer of shares inter vivos

2.1.1 Forma e formalidades

Form and formalities.

2.1.2. Limitaçôes à transmissão

Limitations on transfer

2.1.3. Direito de preferência

Preemptive rights

2.1.4. Impasses

Deadlocks

2.2. Transmissão por morte

Transfers due to death.

3. Contitularidade de quota

Joint holding of shares 
4. Exoneração de sócio Withdrawal of shareholders

5. Exclusão de sócio Exclusion of shareholders.

6. Valores de liquidação das quotas Shareliquidation values

7. Conselho consultivo Advisory board.

\section{III - DA GERÊNCIA} BOARD OF DIRECTORS

1. Composição Composition.

2. Designação e destituição dos gerentes Appointing and removing directors.....

3. Remuneração dos gerentes Remuneration of directors

4. Deveres dos gerentes Duties of directors. 46

5. Negócios entre a sociedade e partes relacionadas Transactions between the company and related parties. 


\section{SUMÁRIO EXECUTIVO}

O Guia de Boas Práticas nas PME-Sociedades por Quotas contém Recomendações sobre diversas matérias que são de especial interesse para as referidas sociedades e divididas pelas seguintes partes:

I - Da constituição e financiamento;

II - Dos sócios;

III - Da gerência.

No Guia, cada Recomendação contém informaçóes acerca do regime legal e comentários breves que justificam as soluçôes propostas. Este Sumário Executivo reúne todas as Recomendaçôes com vista a facilitar o conhecimento das mesmas.

\section{I - DA CONSTITUIÇÃO E FINAN- CIAMENTO}

\section{Formaçáo}

Quando seja escolhido o procedimento "empresa na hora", além da opção standard por uma firma composta por uma expressão de fantasia, escolhida no momento de uma lista oficial,

\section{EXECUTIVE SUMMARY}

The Best Practice Guide for SMEs - Private Limited Liability Companies provides Recommendations on issues that may be considered specially interesting for those companies, divided in three parts:

I - Incorporation and financing

II - Shareholders

III - Board of directors

In this Guide, each Recommendation contains informations on the aplicable legal provisions, and short comments to justify it. This Executive Summary gives a global overview on all the Recommendations in order to facilitate knowledgment of them.

\section{I - INCORPORATION AND FINAN- CING}

\section{Formation}

When the 'firm on the spot' procedure is chosen, in addition to the standard option of a nondescriptive firm name, chosen during the procedure from an official list, we recommend that the 
recomenda-se que os sócios fundadores ponderem a opção por uma firma composta pelos nomes de algum ou alguns deles e/ou pela adição de uma referência à atividade que constituirá o objeto social (sem necessidade, em qualquer caso, de obter previamente um certificado de admissibilidade de firma).

Recomenda-se também que os estatutos da sociedade constituída segundo o procedimento "empresa na hora" sejam alterados segundo a conveniência dos sócios para neles se incluírem cláusulas não contempladas nos (poucos e curtos) modelos de estatutos disponíveis para esse procedimento.

\section{Financiamento}

Recomenda-se que as sociedades evitem uma exposição exagerada ao endividamento, e promovam o reforço dos capitais próprios. Devem, pois, constituir capital social e reservas adequados ao desenvolvimento da atividade social - ponderando também, quanto àquele, a conveniência da entrada de sociedades de capital de risco (L 18/2015) ou de investimento mobiliário para fomento da economia (DL 77/2017) e/ou os incentivos fiscais à remuneração convencional do capital social (EBF, art. $\left.41 .^{\circ}-\mathrm{A}\right)$ e, quanto founding shareholders consider the option of a firm name made from one or more of their own names and/or the addition of a reference to the activity that will comprise the company's purpose (without needing, in any event, to obtain a certificate beforehand attesting that the firm name is permitted).

It is also recommended that the articles of association of companies incorporated using the 'firm on the spot' procedure be amended in due time to include clauses not contained in the template articles that are available for this procedure (which are not numerous and have limited content).

\section{Financing}

We recommend that companies avoid excessive exposure to debt and promote the strengthening of equity capital. As such, they should establish sufficient share capital and reserves to carry out the activity of the company and also, in that regard, consider the advantages of admitting venture capital companies (Law no. $18 / 2015)$ or of investment in securities to stimulate the economy (Decree-Law no. 77/2017) and/ or tax incentives for the deduction from taxable income of part of the capital contributions made by the shareholders (Article 41-A EBF, 
às reservas, os incentivos fiscais ao robustecimento dos capitais próprios através da dedução por lucros retidos e reinvestidos (Código Fiscal do Investimento, aprovado pelo DL 162/2014).

Ocorrendo perda de metade do capital (art. 35..$^{\circ}$ do CSC), recomenda-se que os sócios realizem entradas para reforço da cobertura do capital, aproveitando também o direito a dedução em sede de IRS (art. 43. ${ }^{\circ}-\mathrm{B}$ do EBF).

\section{II - Dos sócIos}

\section{Deliberaçóes dos sócios}

Recomenda-se que, tanto quanto possível, os sócios adotem deliberaçôes em assembleia geral (convocada ou universal), aproveitando as virtualidades da colegialidade/ ponderação.

Quando todos os sócios concordem com determinada decisão, mas sem que a mesma seja adotada em reunião/ assembleia geral, ela deve ser registada como deliberação unânime por escrito, não como deliberação tomada por unanimidade em assembleia geral (inexistente).

\section{Transmissáo de quotas}

Recomenda-se que, antes $\mathrm{da}$ conclusão da transmissão de quota, o adquirente e/ou o the Law on Tax Benefits, approved by Decree-Law no. 215/89, as amended) and, as regards reserves, tax incentives to strengthen equity capital by means of deduction of retained and reinvested earnings (Investment Tax Code, approved by Decree-Law no. 162/2014).

In the event of the loss of half of the capital (Article 35 CSC), we recommend that the shareholders make contributions to strengthen the share capital and also avail themselves of the right to deduct from personal income tax (IRS) (Article 43-B EBF).

\section{II - SHAREHOLDERS}

\section{Shareholders' decisions}

We recommend that, whenever possible, shareholders adopt decisions at a (convened or universal) general meeting, to harness the benefits of collegiality/evaluation.

When all shareholders agree on a specific decision but it is not adopted at a meeting/general meeting, it must be recorded as a unanimous decision in writing, not as a decision taken unanimously at a (non-existent) general meeting.

\section{Transfer of shares}

Before the transfer of shares is completed, the acquirer and/or 
transmitente acedam não apenas aos dados do registo comercial, mas também aos dados arquivados na sociedade, a fim de ser assegurado o trato sucessivo.

Recomenda-se que os sócios façam uso das faculdades de conformação dos estatutos, ora fechando (mais), ora abrindo a sociedade à entrada de novos sócios, consoante pretendam uma sociedade de carácter mais, ou menos, pessoalístico, fundada em fortes relaçóes de confiança mútua (sobretudo quando a sociedade seja familiar) ou nem tanto.

Quando os sócios pretendam limitar a possibilidade de entrada de terceiros na sociedade ou manter determinada proporção nas relaçôes de poder entre os sócios, é recomendável estipular nos estatutos que, em caso de cessáo de quota, os sócios (ou alguns deles - por exemplo, os pertencentes ao ramo familiar em que o cedente se integra) e (eventualmente e em segunda linha) a sociedade têm direito de preferência com eficácia real.

Recomenda-se a estipulação nos estatutos de cláusulas de resolução de impasses, como a de roleta, roleta modificada ou leilão.

Recomenda-se que seja ponderada a utilidade de cláusulas estatutárias que afastem a transmissão de quotas aos sucessores do transferor is recommended to access not only the data in the commercial register, but also the data filed at the company, to ensure succession in title.

Shareholders are recommended to make use of their powers to shape the articles of association, at times imposing (further) restrictions, at times opening the company up to new shareholders, depending on whether they want the focus of the company to be personal to a greater or lesser degree, based on strong relationships of trust (especially when it is a family business) or not.

If shareholders wish to limit the possibility of third parties entering the company or maintain a certain ratio in the power relations between shareholders, it is advisable to stipulate in the articles of association that, in the event of a transfer of shares shareholders (or some of them - for example, members of the family branch to which the transferor belongs) and (potentially and in the second instance) the company have in rem preemptive rights.

We recommend that deadlock resolution clauses, such as Russian roulette, modified Russian roulette or auction, be stipulated in the articles of association.

We recommend that shareholders evaluate the advantages 
falecido ou de cláusulas que sujeitem essa transmissão a certos requisitos. Aquela ponderação deve ter em conta, designadamente, o interesse em manter certos equilíbrios na sociedade e em assegurar a verificaçáo de certos aspetos relativamente ao sucessor.

Em qualquer caso, devem ser devidamente avaliadas as consequências da aplicação das cláusulas (por exemplo, quanto à possibilidade de a sociedade adquirir uma quota própria, quanto à existência de sócio ou terceiro interessado em adquirir a quota, quanto aos casos em que dois ou mais sócios estão interessados em adquirir a quota, quanto à amortização).

\section{Contitularidade de quota}

É recomendável que os contitulares designem tão cedo quanto possível um representante comum competente e diligente, promotor e cumpridor das deliberaçóes dos contitulares necessárias ou convenientes.

\section{Exoneraçáo de sócio}

Também porque a saída pela via da cessão de quotas pode ser muito difícil ou financeiramente desajustada, recomenda-se a inclusão nos estatutos de cláusulas permitindo a exoneração por causas não previstas na lei - por of article clauses that prevent the transfer of shares to the deceased's successors, or clauses that make such a transfer conditional on certain requirements. This evaluation should consider, among others, the benefits of maintaining a certain balance in the company and ensuring that certain issues are verified regarding the successors.

In any event, the consequences of operating the clauses should be properly assessed (regarding, for example, the possibility of the company acquiring own shares, a shareholder or third party who may be interested in acquiring the share, the cases in which two or more shareholders are interested in acquiring the share, the redemption itself).

\section{Joint holding of shares}

We recommend that co-owners name a competent and dedicated common representative as soon as possible, to advance and implement any necessary or pertinent decisions made by the co-owners.

\section{Withdrawal of shareholders}

In addition, because the exit by means of share transfer can be very difficult or financially burdensome, we recommend including clauses in the articles of association to permit withdrawal for 
exemplo, quando um sócio tenha de mudar de residência para local distante da sede social, ou atinja certa idade, ou contraia doença prolongada, ou assuma cargo público.

\section{Exclusão de sócio}

Para reforço da prevenção de comportamentos e situaçôes gravemente prejudiciais para a sociedade e para reação mais célere - por deliberação dos sócios, em lugar de ter de recorrer a tribunal -, recomenda-se que os estatutos estabeleçam causas de exclusão respeitantes ao comportamento de sócios (por exemplo, aproveitamento indevido de oportunidades de negócios da sociedade, concorrência desleal, apropriação ilícita de bens sociais, propositura frequente de açóes chicaneiras contra a sociedade) ou a certas situaçôes em que eles incorram (por exemplo, acompanhamento de maior ou insolvência declarados judicialmente).

\section{Valores de liquidação das quotas}

Para prevenir dificuldades e litígios na avaliação de quotas, é recomendável que os estatutos estipulem critérios simples de fixação dos valores de liquidação, por exemplo o valor resultante do último balanço aprovado ou reasons not envisaged by law - for example, when a shareholder has to change place of residence to a location distant from the registered office, reaches a certain age, suffers a prolonged illness or takes up public office.

\section{Exclusion of shareholders}

To strengthen the prevention of conducts and situations that cause serious detriment to the company and to facilitate a more agile response - by shareholders' decision - it is recommended that the articles of association establish exclusion causes with regard to the conduct of shareholders (for example, improper use of the company's business opportunities, unfair competition, misappropriation of company assets, frequent duplicitous lawsuits against the company) or certain situations in which they are involved (for example, insolvency declared by a court).

\section{Share liquidation values}

To avoid difficulties and disputes in the evaluation of shares, we recommend that the articles of association set out simple criteria for establishing liquidation values, for example the value derived from the most recently adopted balance sheet or the nominal value of the shares, with correction 
o valor nominal das quotas, eventualmente com fatores de correção para os casos de manifesta desproporção entre o valor real e o que se alcança por aqueles critérios.

\section{Conselho consultivo}

Em algumas sociedades, especialmente familiares, é recomendável a constituição de um conselho consultivo composto por sócios e não sócios para aproveitamento do saber e experiência dos sócios mais antigos e para a integração progressiva de sócios mais novos e de futuros sócios na vida da sociedade.

\section{III - DA GERÊNCIA}

\section{Composiçáo}

Tendo em conta a dimensão e complexidade da empresa da sociedade e a competência e disponibilidade do(s) sócio(s), recomenda-se a integração na gerência de um ou mais gestores profissionais não sócios.

\section{Designação e destituição dos gerentes}

Para promover políticas de segurança jurídica e de reconhecimento do mérito, recomenda-se que os estatutos estabeleçam a designação por prazo certo (sem factors where necessary if there is a manifest disproportion between the real value and the value calculated using such criteria.

\section{Advisory board}

In some companies, especially family enterprises, it is recommendable to set up an advisory board formed of shareholders and non-shareholders to draw on the knowledge and experience of older shareholders, and to progressively incorporate younger and future shareholders into the life of the company.

\section{III - BOARD OF DIRECTORS}

\section{Composition}

Taking into account the size and complexity of the company business, and the capacity and availability of the shareholder(s), we recommend including one or more professional managers who are not shareholders on the board of directors.

\section{Appointing and removing di- rectors \\ To promote policies that pro-} vide legal certainty and recognise achievement, we recommend that the articles of association establish that directors shall be appointed for a set term (subject to possible 
prejuízo de possíveis reeleiçóes) e a destituiçãao só com justa causa.

\section{Remuneraçáo dos gerentes}

Recomenda-se que a fixação da remuneração de cada gerente seja feita anualmente, com discriminação do montante em dinheiro e das eventuais componentes não monetárias. Recomenda-se também que as "gratificaçôes» aos gerentes sejam concedidas somente quando os estatutos da sociedade as autorizem.

\section{Deveres dos gerentes}

Recomenda-se que os gerentes de uma sociedade que entre em situação económica difícil ou de insolvência iminente cumpram os deveres de cuidado e de lealdade sem descurarem os direitos e interesses dos credores sociais. Se a insolvência for inevitável, não devem os gerentes continuar a atividade da sociedade sem pedir a declaraçáo judicial de insolvência.

Se for possível a recuperação da empresa da sociedade, os gerentes, independentemente de possíveis deliberaçóes dos sócios, devem adotar medidas que evitem a insolvência - por exemplo, estabelecer negociaçóes com os credores, iniciar um PER (Processo Especial de Revitalização) ou um RERE (Regime Extraju- re-election) and may only be removed with good cause.

\section{Remuneration of directors}

It is recommended that each director's remuneration be set annually, with a breakdown of the amount of money and any non-monetary components. It is also recommended that 'bonuses' be granted to directors solely if they are authorised by the articles of association.

\section{Duties of directors}

It is recommended that the directors of a company that runs into a situation of economic difficulty or imminent insolvency should perform their duties of care and loyalty without disregarding the rights and interests of the company's creditors.

If insolvency is unavoidable, the directors should not continue the activity of the company without requesting a judicial declaration of insolvency.

If the company can be recovered, the directors, notwithstanding possible decisions by the shareholders, should take steps to avoid insolvency - for example, hold negotiations with creditors, initiate a PER (Special Revitalisation Procedure) or an RERE (Extra-Judicial Business Recovery Scheme). 
dicial de Recuperação de Empresas).

\section{Negócios entre a sociedade e partes relacionadas}

$\mathrm{Na}$ falta de disposiçáo específica para as sociedades pluripessoais, recomenda-se que os negócios entre a sociedade e um sócio (ou uma pessoa interposta), salvo quando realizados no âmbito da atividade corrente da sociedade e em condiçóes normais de mercado, sejam autorizados por deliberação da gerência; no caso de o sócio ser o gerente único, a autorização deve ser dada por deliberação dos sócios.

Recomenda-se também, relativamente aos negócios entre a sociedade e um gerente (ou pessoa interposta) - tendo em vista o art. 397. ${ }^{\circ}$ do CSC (aplicável por analogia): a não concessão de empréstimos ou créditos ao gerente, sob pena de nulidade; a autorização por deliberação da gerência ou, se esta for unipessoal, por deliberação dos sócios, e o parecer favorável do órgão de fiscalização (se existir) para os demais negócios (também sob pena de nulidade), excetuados os negócios compreendidos na atividade corrente da sociedade e celebrados em condiçóes normais de mercado.

\section{Transactions between the company and related parties}

In the absence of a specific provision for companies with more than one shareholder, we recommend that transactions between the company and a shareholder (or an intermediary), except when conducted in the course of the company's ongoing operations and under normal market conditions, be authorised by decision of the board of directors; if the shareholder is the sole director, authorisation should be granted by decision of the shareholders.

As regards transactions between the company and a director (or intermediary), it is also advisable - in view of Article 397 of the CSC (applicable by analogy): not to grant loans or credits to directors, subject to be null and void; to provide authorisation by decision of the board of directors or, for companies with a sole director, by decision of the shareholders and assent of the supervisory body (if applicable) for all other transactions (also otherwise null and void), except for transactions that form part of the ongoing operations of the company and are conducted under normal market conditions. 



\section{PREÂMBULO}

Os autores deste Guia são membros de um grupo (mais alargado) que, no âmbito do Instituto Jurídico da Faculdade de Direito da Universidade de Coimbra, se propôs investigar sobre "As PME's: Promoção da Inovação, Crescimento e Competitividade".

Desde o inicio, foi preocupação do grupo recolher informação (primordialmente no terreno, para lá dos livros) acerca das PME, tratá-la e debatê-la com quem lida com elas. Beneficiámos, para isso, da prestimosa colaboração de empresários e associaçóes empresariais $e$ de sociedades de advogados. Depois, o grupo procurou ouvir também e dialogar com universitários de outros países acerca da temática PME's.

Em resultado daqueles contactos e das investigaçôes empreendidas, foram publicados pelo Instituto Jurídico três livros dando conta de outros tantos colóquios por nós organizados: PME's e empresas familiares perante o ambiente societário, fiscal e laboral (2016), Congresso Internacional As Pequenas e Médias Empresas e o

\section{PREAMBLE}

The authors of this Guide are members of a (broader) group that set out to investigate 'SMEs: Promotion of Innovation, Growth and Competitiveness' within the framework of the Institute for Legal Research at the Faculty of Law, University of Coimbra.

From the outset, the group's concern was to gather information (primarily on the ground, beyond the sphere of books) about SMEs and to process and debate it with those who deal with them. To do so, we were able to benefit from valuable contributions from entrepreneurs, trade and industrial associations, and law firms. Subsequently, the group also strove to listen to and engage with scholars from other countries on the topic of SMEs.

As a result of these contacts and conducted research, three books were published by the Institute for Legal Research, reporting on the three conferences we have organised: PME's e empresas familiares perante o ambiente societário, fiscal e laboral (SMEs and family businesses and the corporate, tax and labour environment) (2016), Con- 
Direito (2017), As PME perante o (novo) direito da insolvência (2018).

Fechando o presente ciclo de investigação jurídico-societária sobre PME's, oferecemos o Guia de Boas Práticas nas PME-Sociedades por Quotas.

É sabido que as empresas portuguesas são, em esmagadora maioria, PME. Que se apresentam dominantemente sob a veste de sociedades por quotas.

Curiosamente (ou não), os textos jurídico-societários recomendatórios (guias, princípios, códigos, etc.) estrangeiros, internacionais ou portugueses tratam quase exclusivamente das sociedades anónimas, em especial das cotadas. Eis, pois, aqui um contributo para, entre nós, cobrir uma lacuna.

O Guia está estruturado em três capitulos, cada um com vários números. Cada número subdivide-se em dois (p. ex., o n. ${ }^{o}$ 1. subdivide-se em 1.1 e 1.2). O primeiro subnúmero informa sobre o que diz (ou não diz) a lei acerca de certa matéria (impondo ou permitindo); o segundo contém, em negrito, a ou as recomendaçóes sobre a mesma matéria.

Parece-nos que se justifica esta combinação entre recomendaçóes propriamente ditas (não vinculativas) e lei: fica facilitado para mui- gresso Internacional As Pequenas e Médias Empresas e o Direito (International Congress Small and Medium Enterprises and the Law) (2017), As PME perante o (novo) direito da insolvência (SMEs and (new) insolvency law) (2018).

To complete this cycle of legal and corporate research on SMEs, we now present the Best Practice Guide for SMEs - Private Limited Liability Companies (Sociedade por Quotas) (hereinafter "PLLC/SQ").

It is well known that the overwhelming majority of Portuguese companies are SMEs. These primarily take the form of PLLC/SQ.

However, foreign, international and Portuguese texts providing recommendations on company law (guides, principles, codes, etc.) deal almost exclusively with public limited companies, especially listed companies. This offering aims at bridging this gap.

The Guide is structured in three chapters, each with various numbered items. Each item is subdivided into two (e.g. no. 1. is subdivided into 1.1 and 1.2). The first subitem gives information on what the law says (or does not say) regarding a specific matter (in a mandatory or simply enabling guise); the second, in bold, provides our recommendation(s) on the same matter.

In our view this combination of actual (non-binding) recom- 
tos destinatários do Guia - sócios e gerentes - o (melhor) conhecimento do que diz a lei sobre assuntos que a eles respeitam e que não deve ser ignorado. mendations and law is relevant: for many users of the Guide - shareholders and directors - it provides (better) understanding of what the law says on matters that are of concern to them and that should not be ignored. 



\section{I - DA CONSTITUIÇÃO E FINANCIAMENTO}

\section{FormaÇÃo}

1.1. O processo comum de constituição das sociedades por quotas (previsto no CSC) desdobra-se em três atos (e momentos) principais: o negócio jurídico constituinte (unilateral ou contratual, consoante a sociedade seja unipessoal ou pluripessoal) que deve observar forma especial (normalmente escrito particular com assinatura(s) reconhecida(s) presencialmente); o registo (definitivo) do ato constituinte; e a publicação (em sítio na Internet de acesso público).

Um dos processos especiais de constituição frequentemente utilizado é o previsto no DL 111/ 12005 - "Regime especial de constituição imediata de sociedades" (ou regime "empresa na hora”). É um processo rápido e relativamente simples e económico, e que não dá lugar às complicaçóes que o funcionamento de uma sociedade constituída segundo o procedimento comum pode originar.

\section{I - INCORPORATION AND FINANCING}

\section{FORMATION}

1.1. The ordinary process for incorporation of PLLC/SQ (outlined in the CSC ${ }^{*}$ Commercial Companies Code+) is divided into three main steps (and time frames): a legal act of formation (unilateral or contractual, depending on whether the company is a sole proprietorship or a partnership) which must conform to a special format (usually a private written agreement with signature(s) witnessed in person); (final) registration of the act of formation; publication (on a publicly accessible website).

One of the special incorporation processes that are frequently used is that outlined in Decree-Law no. 111/2005 - 'Special scheme for the immediate incorporation of companies' (or 'firm on the spot' scheme). This is a quick, relatively simple and inexpensive process which does not lead to the complications that the operation of a company established with the ordinary procedure may 
1.2. Quando seja escolhido o procedimento "empresa na hora”, além da opçáo standard por uma firma composta por uma expressáo de fantasia, escolhida no momento de uma lista oficial, recomenda-se que os sócios fundadores ponderem a opçáo por uma firma composta pelos nomes de algum ou alguns deles e/ou pela adiçáo de uma referência atividade que constituirá o objeto social (sem necessidade, em qualquer caso, de obter previamente um certificado de admissibilidade de firma).

Recomenda-se também que os estatutos da sociedade constituída segundo o procedimento "empresa na hora" sejam alterados segundo a conveniência dos sócios para neles se incluírem cláusulas náo contempladas nos (poucos e curtos) modelos de estatutos disponíveis para esse procedimento. create during the various stages of the procedure.

1.2. When the 'firm on the spot' procedure is chosen, in addition to the standard option of a nondescriptive firm name, chosen during the procedure from an official list, we recommend that the founding shareholders consider the option of a firm name made from one or more of their own names and/or the addition of a reference to the activity that will comprise the company's purpose (without needing, in any event, to obtain a certificate beforehand attesting that the firm name is permitted).

It is also recommended that the articles of association of companies incorporated using the 'firm on the spot' procedure be amended in due time to include clauses not contained in the template articles that are available for this procedure (which are not numerous and have limited content).

\section{Comments}

(a) There are currently two models or templates of articles of association for PLLC/SQ, three for public limited liability companies (sociedades anónimas) and one for one-person private limited compa- 
uns dos outros pelo grau de detalhe e amplitude da regulamentação: os mais complexos incluem cláusulas adicionais à regulamentação-base constante dos modelos mais simples. É possivel fazer opçóes quanto ao modo de vinculação da sociedade: representação disjunta (actuação de um só gerente ou administrador) ou conjunta (actuação de vários).

Mas ficam de fora diversas possibilidades de modelação do regime da futura sociedade que o Código das Sociedades Comerciais coloca à disposição dos sócios - por ex., cláusulas relativas à exclusáo ou exoneração de sócios, à fixação de maiorias qualificadas para a aprovação de deliberaçóes sobre certos assuntos, à atribuição de direitos especiais, à determinação de regimes particulares para a transmissão (entre vivos ou por sucessão) de participaçóes sociais, etc. Recomenda-se que estas possibilidades sejam consideradas (por exemplo, através da alteração dos estatutos - ver a seguir), por forma a dar expressão a interesses importantes dos sócios e a permitir evitar ou mais facilmente resolver futuros conflitos entre eles.

(b) Quando se queiram incluir nos estatutos cláusulas não contempladas nos modelos de pacto social disponiveis no sistema da "empresa na hora" sem prescindir do recurso a este procedimento (o que significaria registar um pacto social específica e nies (sociedades unipessoais). These models differ in the level of detail and the extent of the rules: the more complex models include additional clauses to the basic rules contained in the simpler ones.

Choices can be made regarding how the company is bound: individual representation (one director or administrator) or joint representation (several).

These templates leave out a number of possibilities for modelling the rules of the future company that the Commercial Companies Code makes available to shareholders such as clauses relating to the exclusion or withdrawal of shareholders, to establishing qualified majorities to adopt decisions on certain matters, to allocating special rights, to setting out specific arrangements for the transfer of shares (quotas) (inter vivos or by succession), etc. We recommend that these possibilities are considered, so as to give expression to important interests on the part of shareholders and to allow future conflicts between them to be avoided or more easily settled.

(b) If one wants the articles of association to include clauses that are not included in the model articles available in the 'firm on the spot' system without abstaining from using this procedure (which would mean registering specific and pre- 
previamente elaborado), pode proceder-se à posterior alteração dos estatutos de modo a neles incluir as cláusulas adicionais, suportando o custo adicional dos emolumentos com $o$ registo das alteraçóes ao pacto social.

\section{FINANCIAMENTO}

2.1. Em regra, o financiamento inicial da sociedade resulta do capital social, ou melhor, das entradas dos sócios correlativas ao capital social (CSC, arts. 25. ${ }^{\circ}$, s., $202 .^{\circ}$, s.). O CSC regula outras (eventuais) contribuiçóes financeiras feitas pelos sócios: suprimentos (arts. 243..$^{\circ}$ s.), prestaçóes acessórias e prestações suplementares (arts. 209. ${ }^{\circ}$, s.). O capital social mínimo (variável) é hoje insignificante: $€ 1$ para a sociedade unipessoal, $€ 2$ para a sociedade de dois sócios, etc. (arts. 201. ${ }^{\circ}$, $\left.219 .^{\circ}, 3\right)$; as prestaçóes acessórias e as suplementares só são obrigatórias quando previstas nos estatutos.

Independentemente dos meios de financiamento regulados na lei societária, é muito frequente o recurso a capitais alheios (crédito bancário, principalmente).

\subsection{Recomenda-se que as so-} ciedades evitem uma exposiçáo exagerada ao endividamento, viously prepared articles of association), the articles can be amended subsequently to include additional clauses (incurring additional costs in the form of fees to register the changes to the articles).

\section{FINANCING}

2.1. As a rule, the initial financing of a company derives from the share capital, or rather from shareholder contributions corresponding to the share capital (Articles 25 et seq. and 202 et seq. CSC). The CSC regulates other (possible) financial contributions made by shareholders: loans (Articles 243 et seq.), ancillary capital contributions and supplementary capital contributions (Articles 209 et seq.). The minimum (variable) share capital is now an insignificant amount: $€ 1$ for a one-person company, $€ 2$ when there are two shareholders, etc. (Articles 201 and 219(3)); ancillary and supplementary capital contributions are only mandatory if they are laid down in the articles of association. Irrespective of the means of financing regulated by corporate law, borrowed capital (principally bank loans) is very frequently used.

\subsection{We recommend that com- panies avoid excessive expo-}


e promovam o reforço dos capitais próprios. Devem, pois, constituir capital social e reservas adequados ao desenvolvimento da atividade social - ponderando também, quanto àquele, a conveniência da entrada de sociedades de capital de risco ( $\mathrm{L}$ 18/2015) ou de investimento mobiliário para fomento da economia (DL 77/2017) e/ou os incentivos fiscais à remuneraçáo convencional do capital social (EBF, art. $\left.41 .^{\circ}-\mathrm{A}\right) \mathbf{e}$, quanto às reservas, os incentivos fiscais ao robustecimento dos capitais próprios através da deduçáo por lucros retidos e reinvestidos (Código Fiscal do Investimento, aprovado pelo DL 162/2014).

Ocorrendo perda de metade do capital (art. 35..$^{\circ}$ do CSC), recomenda-se que os sócios realizem entradas para reforço da cobertura do capital, aproveitando também o direito a dedução em sede de IRS (art. 43. ${ }^{\circ}-\mathrm{B}$ do $\mathrm{EBF}$ ).

\section{Comentário}

(a) A elevada dependência do financiamento através de capital sure to debt and promote the strengthening of equity capital. As such, they should establish sufficient share capital and reserves to carry out the activity of the company - and also, in that regard, consider the advantages of admitting venture capital companies (Law no. 18/2015) or of investment in securities to stimulate the economy (Decree-Law no. 77/2017) and/or tax incentives for the deduction from taxable income of part of the capital contributions made by the shareholders (Article 41-A EBF, the Law on Tax Benefits, approved by Decree-Law no. $215 / 89$, as amended) and, as regards reserves, tax incentives to strengthen equity capital by means of deduction of retained and reinvested earnings (Investment Tax Code, approved by Decree-Law no. 162/2014).

In the event of the loss of half of the capital (Article 35 CSC), we recommend that the shareholders make contributions to strengthen the share capital and also avail themselves of the right to deduct from personal income tax (IRS) (Article 43-B EBF).

\section{Comments}

(a) The high dependence on $f$ nancing through borrowed capital, 
alheio, sobretudo de fonte bancária, é amplamente reconhecida como um problema que afeta grande parte das empresas. Importará que, no desenho da constituição financeira das sociedades, sejam consideradas as necessidades de capital da empresa, independentemente dos minimos legalmente exigidos. Favorecendo uma tal disponibilização de meios próprios de financiamento, a lei fiscal incentiva a remuneraçáo convencional do capital social, assim como a sua recapitalização. Depois, devem ser considerados os demais meios de financiamento regulados na lei societária (prestaçóes suplementares, prestaçóes acessórias, suprimentos), os quais, ainda que todos provenientes dos sócios, serão classificáveis como capital próprio ou capital alheio, consoante os casos. Não deve ainda esquecer-se a possibilidade de os credores proporem à sociedade a conversáo dos seus créditos em capital social (L 7/2018).

(b) Abrindo-se a sociedade a financiamento externo, ele também poderá assumir qualquer uma dessas duas feiçóes. Se a emissão de títulos de divida continua hoje a ser inexistente ou escassa nas pequenas e médias empresas, com o acesso a segmentos alternativos do mercado de capitais a ser, para já, apenas um objetivo para cujo atingimento é ainda necessário criar condiçóes propicias (conforme reconhecem, desig- from banks in particular, is widely recognised as a problem affecting many companies. It is important when shaping the financial structure of companies that their needs for capital are taken into consideration, irrespective of the minima required by law. Tax law, favouring such a provision of the company's own means of financing, encourages deduction from taxable income of part of the capital contributions made by the shareholders, along with recapitalisation. Subsequently, the other means of financing regulated by company law should be considered (supplementary capital contributions, ancillary capital contributions, loans), which, although originating from the shareholders, will be classified as equity or borrowed capital, as applicable. Attention should also be paid to the possibility of creditors proposing the conversion of their credits into share capital (Law no. 7/2018).

(b) If the company is opened to external funding, this may also take either of these two forms. While issuance of debt securities continues at present to be non-existent or minimal in small and medium-sized enterprises and access to alternative segments of the capital market is currently only a goal for which it is still necessary to create favourable conditions (as acknowledged, in particular, by CMVM, the Por- 
nadamente, a CMVM e a OCDE: tuguese Securities Market Com"Improving Access to Capital for mission, and OECD: Improving Portuguese Companies: a Survey Access to Capital for Portuguese of Unlisted Companies", 4 de ju- Companies: a Survey of Unlisted nho de 2020), alguns meios existem Companies', 4 June 2020), some no mercado para a promoção do re- tools exist in the market to promote forço dos capitais próprios, tais como the strengthening of equity capital, a participação de sociedades de ca- such as the participation of venture pital de risco ou o investimento mobiliário para fomento da economia. capital companies or investment in securities to stimulate the economy. 



\section{II - Dos sócios}

\section{Deliberações dOS Sócios}

1.1. Nas sociedades pluripessoais, os sócios podem adotar deliberaçóes escolhendo entre quatro procedimentos: deliberaçóes em assembleia geral convocada, deliberações em assembleia universal (todos os sócios estão presentes em certo momento e lugar e, independentemente de formalidades prévias, todos concordam na constituição da assembleia para que se delibere sobre determinado(s) assunto(s)), deliberaçôes unânimes por escrito (uma decisão é exarada em documento(s) escrito(s) assinado(s) por todos os sócios) e deliberaçôes por voto escrito - CSC, arts. 54. ${ }^{\circ}, 247 .{ }^{\circ}$.

Nas sociedades unipessoais, a competência da assembleia geral (das sociedades pluripessoais) é exercida mediante decisóes do sócio único, que devem ser registadas em ata por ele assinada (art. 270. ${ }^{\circ}$-E).

1.2. Recomenda-se que, tanto quanto possível, os sócios adotem deliberaçóes em assembleia

\section{II - SHAREHOLDERS}

\section{ShAREHOLDERS' DeCISIONS}

1.1. In companies with more than one shareholder, shareholders can adopt resolutions through one of four procedures: decisions adopted at a convened general meeting, decisions taken at a universal meeting (all shareholders are present at a specific time and place and, irrespective of prior formalities, agree to establish the meeting so that a decision can be adopted on one or more specific subjects), unanimous decisions in writing (a resolution is recorded on one or more written document(s) signed by all the shareholders) and decisions adopted by a written vote Articles 54 and 247 CSC.

In one-person companies, the powers of the general meeting (of partnership companies) are exercised through decisions taken by the sole shareholder, which must be entered in a record signed by him or her (Article 270-E).

1.2. We recommend that, whenever possible, shareholders adopt decisions at a (convened 
geral (convocada ou universal), aproveitando as virtualidades da colegialidadel ponderaçáo.

Quando todos os sócios concordem com determinada decisáo, mas sem que a mesma seja adotada em reuniáo/ assembleia geral, ela deve ser registada como deliberaçáo unânime por escrito, náo como deliberaçáo tomada por unanimidade em assembleia geral (inexistente).

\section{Comentário}

(a) As assembleias gerais possibilitam a participaçáo efetiva de cada sócio na vida da sociedade, com questionamentos, trocas de informação, debates, propostas e contrapropostas, em suma promovem maior transparência e decisóes mais refletidas.

(b) É muito frequente dizer-se em atas que foram tomadas deliberaçôes por unanimidade em assembleia geral (convocada ou universal), apesar de não se ter realizado qualquer assembleia Ireuniáo dos sócios. Esta prática talvez se explique por ainda persistir a ideia - errada - de que as deliberaçóes têm de ser tomadas em assembleia geral.

Frequentemente também, aquelas atas são assinadas por todos os sócios. O que pode permitir (re)qualificar as deliberaçóes, não como or universal) general meeting, to harness the benefits of collegiality/evaluation.

When all shareholders agree on a specific decision but it is not adopted at a meeting/general meeting, it must be recorded as a unanimous decision in writing, not as a decision taken unanimously at a (non-existent) general meeting.

\section{Comments}

(a) General meetings facilitate the effective participation of every shareholder in the life of the company, with questions, exchanges of information, debates, proposals and counterproposals; in short, they promote greater transparency and more considered decisions.

(b) Minutes frequently state that decisions were adopted unanimously at a (convened or universal) general meeting, despite the fact that no meeting of shareholders was held. This practice may be explained by the persistent - and erroneous - belief that decisions must be taken at a general meeting.

These minutes are also often signed by all the shareholders. This may allow these decisions to be (re)classified, not as decisions adopted at a general meeting, but as unanimous 
deliberaçōes em assembleia geral, mas como deliberaçóes unânimes por escrito - assinando todos os sócios, todos declaram concordar com as decisóes relatadas em ata.

Mas se, por qualquer razão, algum sócio não assina uma dessas atas, então é possivel que as "deliberaçôes" respetivas sejam consideradas juridicamente inexistentes (nem são deliberaçôes adotadas em assembleia, nem são deliberaçôes unânimes por escrito), podendo a inexistência ser invocada por qualquer pessoa a todo o tempo.

\section{TRANSMISSÃO DE QUOTAS}

\subsection{Transmissáo de quotas entre vivos}

\subsubsection{Forma e formalidades}

2.1.1.1. A transmissão de quota deve ser feita por escrito (CSC, art. $\left.228 .^{\circ}, 1\right)$ e registada por depósito (CRCom., arts. 3. ${ }^{\circ}, 1, \mathrm{c}$ ), 53. $\left.{ }^{\circ}-A, 5, a\right)$ ). É a sociedade que promove o registo, tendo o dever de controlar a regularidade da transmissão (CSC, arts. 242. ${ }^{-}$ $-B, s$.$) .$

\subsubsection{Recomenda-se que, an-} tes da conclusáo da transmissáo de quota, o adquirente e/ ou o transmitente acedam náo apenas aos dados do registo co- decisions in writing - all the shareholders sign and, as such, they all state that they agree with the decisions entered in the minutes.

But if, for any reason, one of the shareholders does not sign a particular set of minutes, the corresponding 'decisions' may be considered legally non-existent (they are not decisions adopted at a meeting or by unanimous decisions in writing), and this non-existence may be invoked by anyone at any time.

\section{TRANSFER OF SHARES}

\subsection{Transfer of shares inter vivos}

2.1.1 Form and formalities

2.1.1.1. The transfer of shares must be performed in writing (Article 228(1) CSC), and registered by presentation of the document (Articles 3(1)(c) and 53-A(5)(a) CRCom "Commercial Registry Code"). The company carries out the registration, and is required to verify the legality of the transfer (Articles 242-B et seq. CSC.).

2.1.1.2. Before the transfer of shares is completed, the acquirer and/or transferor is recommended to access not only the 
mercial, mas também aos dados arquivados na sociedade, a fim de ser assegurado o trato sucessivo.

\section{Comentário}

(a) Quem pretende adquirir uma quota de outrem tem, normalmente, interesse em adquirir de quem é titular dessa mesma quota. Porém, os registos de cessóes de quotas são efetuados, hoje, por depósito. $O$ registo da titularidade de uma quota em nome de um determinado sujeito náo é garantia de que este último seja titular da quota. Tanto mais que o art. $47 . .^{\circ}$ do CRCom. apenas exige que a viabilidade do pedido de registo perante, designadamente, os registos anteriores e com a verificação da legitimidade dos interessados, seja apreciada quanto ao registo por transcrição, que não se confunde com o registo por depósito. É a sociedade por quotas que, para promover o registo de atos modificativos da titularidade de quotas e de direitos sobre elas, deve verificar se nesses atos interveio o titular registado (art. 242. $\left.{ }^{\circ}-D\right)$. A isso acresce o facto de a cessáo de quotas se bastar hoje com a forma escrita (e, portanto, sem intervenção necessária de notário ou advogado).

\section{data in the commercial register, but also the data filed at the company, to ensure succession in title.}

\section{Comments}

(a) Anybody who intends to acquire a share is usually interested in acquiring it from the holder of the share in question. However, share transfers are currently registered by presentation of the appropriate document. Registering the ownership of a share in the name of a certain individual does not guarantee that the latter is the owner of the share. All the more so since Article 47 CRCom only requires that an assessment be made to determine whether the registration application may proceed in view of, inter alia, prior registrations, and with verification of the legitimacy of the interested parties, for registrations performed by entering details in the register [registo por transcrição], which should not be confused with registrations made by presenting documents [registo por depósito]. For the registration of instruments modifying the ownership of shares and claims to them, it is the responsibility of the company to verify whether the registered holder was a party to those instruments (Article 242-D). In addition, share transfers may now be performed merely in written form (without, therefore, 
(b) Isto mostra que o interessado em adquirir uma quota pouca confiança pode depositar no que está registado quanto à referida quota na conservatória do registo comercial. Mas mostra também que a sociedade deve organizar-se internamente de forma a conseguir identificar as várias transmissóes das quotas em que se divide o seu capital e a controlar a legalidade dos atos que the são apresentados para registo. Lembre-se que é a sociedade que, em regra, vai promover o registo das transmissóes de quotas e, por isso, é a sociedade que tem de verificar se o pedido é viável "em face das disposiçóes legais aplicáveis, dos documentos apresentados e dos registos anteriores, devendo verificar especialmente a legitimidade dos interessados, a regularidade formal dos títulos e a validade dos atos neles contidos» (art. 242. ${ }^{\circ}-E, 1$, do CSC). O rigor na realização dessas tarefas é indispensável, pois a ameaça de responsabilização civil existe (art. 242. ${ }^{\circ}-F, 1$, do CSC). A sociedade por quotas deve manter um adequado registo interno dos factos relativos às quotas e um arquivo dos documentos que os comprovam de forma a poder cumprir as suas obrigaçôes legais. Tudo isto sem prejuizo do registo do beneficiário efetivo que a sociedade por quotas também deve possuir (v. a Lei 89/2017, de 21 de agosto, já alterada). any need for a notary or lawyer to be involved).

(b) This shows that anyone interested in acquiring a share cannot place much trust in the share documentation held at the commercial register. However, it also shows that the company must organise itself internally to be able to identify the various transfers of shares into which its capital is divided, and to verify the legality of the instruments that are presented to it for registration. It should be borne in mind that, as a rule, the company will perform the registration of share transfers and, as such, it is the company's responsibility to verify whether the application may proceed in view of the applicable legal provisions, the documents presented and any prior registrations, with the requirement that the legitimacy of the interested parties, the formal legality of the documents and the validity of the instruments contained therein be specifically verified' (Article 242-E(1) CSC). It is crucial that these tasks be performed meticulously as there is a risk of civil liability (Article 242-F(1) CSC). The company must keep duly organised internal records of the facts concerning its own shares, and a file with the documents proving them, in order to comply with its legal duties. It goes without saying that the company also has to keep its 
(c) A preocupação com o problema exposto não é apenas teórica. O regime do registo por depósito tem gerado insegurança, existindo relatos de casos em que pessoas que querem transmitir verificam que já não têm a quota registada em seu nome, revelando falta de organização interna das sociedades quanto aos aspetos relacionados com as quotas. Embora o registo de titularidade de quota em nome de quem não é o seu titular não confira, só por si, essa mesma titularidade, trará certamente dificuldades ao efetivo titular da quota. Desde logo, porque aquele registo vai gerar desconfiança em eventuais interessados em adquirir a quota. Além disso, e como já vimos, a sociedade só deve promover o registo de atos modificativos da titularidade de quotas e de direitos sobre elas se naqueles atos intervier o titular registado.

\subsubsection{Limitaçóes à transmissão}

2.1.2.1. Em regra (legal dispositiva), a cessão de quotas só é eficaz perante a sociedade quando consentida por esta (normalmente por deliberação dos sócios), salvo se for entre cônjuges, entre ascendentes e descendentes ou entre sócios (CSC, arts. $228 .^{\circ}, 2,230 .^{\circ}$. Derrogando a regra, os estatutos podem proibir a cessão, ou exigir o consentimento (ou condicioná-lo) em casos em que ela é livre segundo beneficial owner's register (see Law 89/2017, published on August, 21, with amendments).

(c) Concern regarding the problem described above is not merely theoretical. The system of registering by presenting documents has created uncertainty, with reports of cases where people wishing to transfer shares discover that they are no longer registered in their name, revealing a lack of internal organisation on the part of companies in share-related matters. Although the registration of share ownership in the name of somebody who is not the owner does not grant ownership per se, it will certainly create difficulties for the actual owner of the share. Primarily because the registration will arouse suspicion in anyone who may be interested in acquiring the share. Moreover, as we have seen, the company should only register instruments modifying the ownership of shares and claims to them if the registered holder is a party to the instruments.

\subsubsection{Limitations on transfer}

2.1.1.2. As a (default legal) rule, a share transfer only has effect in relation to the company when it has the latter's consent (usually by a decision of the shareholders), unless it occurs between spouses, between relatives in the 
a norma dispositiva, ou permiti-la sem consentimento em casos em que este é estabelecido por aquela norma (art. 229. ${ }^{\circ}$ ).

\subsubsection{Recomenda-se que os} sócios façam uso das faculdades de conformaçáo dos estatutos, ora fechando (mais), ora abrindo a sociedade à entrada de novos sócios, consoante pretendam uma sociedade de carácter mais, ou menos, pessoalístico, fundada em fortes relaçóes de confiança mútua (sobretudo quando a sociedade seja familiar) ou nem tanto.

\section{Comentário}

(a) Os sócios das sociedades por quotas devem avaliar ponderadamente em que medida será do interesse da sociedade incluir nos estatutos cláusulas que permitam afastar a entrada de estranhos ou aumentar a viabilidade dessa entrada. As cláusulas estatutárias (ou a falta delas no que diz respeito à exigência legal de consentimento) podem acabar ascending and descending lines or between shareholders (Articles 228(2) and 230 CSC). In derogation from the rule, the articles of association may prohibit transfers or require consent (or restrict it) in cases where transfers are not restricted by the law, or permit them without consent in cases where consent is established by the same law (Article 229).

2.1.2.2. Shareholders are recommended to make use of their powers to shape the articles of association, at times imposing (further) restrictions, at times opening the company up to new shareholders, depending on whether they want the focus of the company to be personal to a greater or lesser degree, based on strong relationships of trust (especially when it is a family business) or not.

\section{Comments}

(a) Shareholders of PLLC/SQ should consider carefully the extent to which it is in the company's interest to include clauses in the articles of association to impede or facilitate the entry of outside parties. Article clauses (or the lack of them regarding legal requirement for consent) may ultimately be used in the future to keep potential inves- 
por, no futuro, servir para afastar da sociedade eventuais investidores com "dinheiro fresco" ou para tentar impedir a saída de um sócio que tenha outros projetos. Os eventuais custos para a sociedade resultantes do funcionamento da cláusula também devem ser tidos em conta. Se, por exemplo, for necessário amortizar ou adquirir a quota, a sociedade tem de acautelar a necessidade de pagar a devida contrapartida (art. 231. $\left.{ }^{\circ}, 1,2, d\right), 3$ e 4 do CSC).

(b) Os estatutos podem servir para tentar manter equilibrios na distribuiçáo do poder dentro da sociedade. As cláusulas que sejam introduzidas devem ser previamente analisadas de forma a ter plena consciência dos seus efeitos não apenas na primeira transmissäo que seja efetuada, mas também em posteriores transmissóes. Isso permitirá evitar consequências indesejadas.

(c) As cláusulas limitativas da transmissibilidade das quotas devem ser redigidas pensando também nas consequências que pode ter a aquisição de uma quota por uma outra sociedade. Em particular, devido ao regime de coligação de sociedades do CSC e, especialmente, aos casos em que é possivel a aquisição das quotas dos sócios minoritários sem o seu consentimento.

(d) Nas sociedades familiares, as cláusulas estatutárias podem abrir tors with 'fresh money' away from the company or to try to prevent the departure of a shareholder who has other projects. Any possible costs for the company resulting from the operation of the clause must also be taken into account. If, for example, it is necessary to redeem or acquire the share, the company must address the need to pay the appropriate consideration (Article 231(1), (2) (d), (3) and (4) CSC).

(b) The articles of association can be used to try to maintain a balance in the distribution of power within the company. Any clauses that are added must be analysed previously in order to fully understand their effects not only in the first transfer that is made, but also in subsequent transfers. This will help to avoid unintended consequences.

(c) Share transfer restrictions must consider the consequences of having another company as a member. In particular, because of the provisions on companies groups, and especially due to squeeze-out rights.

(d) In family companies, article clauses may impede or permit the entry of certain family members or members of branches of the family. For example, it may be justifiable to waive the company's consent for share transfers for collateral relatives or in favour of members of the 
ou fechar a entrada de certos familiares ou de membros de ramos da familia. Pode, por exemplo, justificar-se dispensar o consentimento da sociedade para cessóes de quotas na linha colateral ou a favor de familiares do cônjuge do sócio. Essa pode ser a forma de chamar para a sociedade familiares com aptidóes e vocação para o negócio da família.

(e) Em qualquer caso, considera-se importante que os estatutos sejam redigidos de forma a que seja claro em que casos a cessáo de quotas é livre. Isso trará posteriormente muita segurança aos sócios, permitindo-lhes um melhor planeamento da sua relação com a sociedade.

(f) Por outro lado, será igualmente importante que se pondere $o$ estabelecimento de sançóes para o incumprimento das limitaçôes estatutárias (por exemplo, através de cláusulas de amortização).

(g) As cláusulas estatutárias (ou a sua falta) devem ser vistas pensando também nas exigências que valem para aquela sociedade quanto à alteração do contrato de sociedade e, em particular, no que diz respeito ao quorum. Com efeito, a introdução de uma cláusula estatutária relativa à transmissibilidade das quotas pode acabar por ser de pouca utilidade se, depois, é relativamente fácil alterar os estatutos suprimindo family of the shareholder's spouse. This can be a way of bringing family members with skills and vocations into the family business.

(e) In any event, we consider it important to draft the articles of association in a manner that clearly indicates the cases in which share transfer is not restricted. This will subsequently provide a great deal of certainty for the shareholders and allow them to plan their relationship with the company more effectively.

(f) On the other hand, it is also important to weigh sanctions for those who violate share transfer restrictions (for instance, amortization clauses).

(g) The clauses in the articles of association (or the lack thereof) must also be considered in light of the requirements that apply to the company regarding modification of the articles and, in particular, quorum. Indeed, adding a clause to the articles on the transferability of shares may prove to be of little use if at a later date it is relatively easy to amend the articles by deleting the clause. Article 265(1) CSC authorises amendments to the articles of association with a majority of three quarters of the votes corresponding to the share capital, but also it allows the articles to establish 
essa mesma cláusula. O art. 265. ${ }^{\circ}$, 1 , do CSC permite alterar o contrato de sociedade por maioria de três quartos dos votos correspondentes ao capital social, mas também permite que o contrato de sociedade estabeleça a necessidade de atingir um número mais elevado de votos. A distribuiçáo do poder na sociedade pode justificar que se utilize esta última possibilidade.

\subsubsection{Direito de preferência}

2.1.3.1. O CSC não atribui direito de preferência aos sócios ou à sociedade em caso de cessáo de quotas. Mas não impede que os estatutos sociais o atribuam - embora a eficácia da cessão para com a sociedade não possa ficar dependente do cumprimento, pelo cedente, da obrigação de preferência (art. 229. ${ }^{\circ}, 5$, do CSC).

2.1.3.2. Quando os sócios pretendam limitar a possibilidade de entrada de terceiros na sociedade ou manter determinada proporçáo nas relaçóes de poder entre os sócios, é recomendável estipular nos estatutos que, em caso de cessáo de quota, os sócios (ou alguns deles - por exemplo, os pertencentes ao ramo familiar em que o cedente se integra) e (eventualmente e em segunda linha) a sociedade têm direito de preferência com eficácia real. a requirement for a larger number of votes. The distribution of power in the company may justify the use of the latter possibility.

\subsubsection{Preemptive rights}

2.1.3.1. The CSC does not confer preemptive rights to shareholders or the company in the event of a transfer of shares. But it does not prevent the articles of association from conferring these rights - although the effectiveness of the transfer to the company cannot be dependent on performance, by the transferor, of the preemptive obligation (Article 229(5) CSC).

\subsubsection{If shareholders wish} to limit the possibility of third parties entering the company or maintain a certain ratio in the power relations between shareholders, it is advisable to stipulate in the articles of association that, in the event of a transfer of shares, shareholders (or some of them - for example, members of the family branch to which the transferor belongs) and (potentially and in the second instance) the company have in rem preemptive rights. 


\section{Comentário}

(a) A legalidade das cláusulas estatutárias de preferência tem sido discutida. E isto porque, desde logo, do art. 229. o, 5, do CSC resulta que a eficácia da cessão para com a sociedade não pode ficar dependente de uma cláusula de preferência. No entanto, é possivel redigir essa cláusula tendo em conta aquele regime legal.

(b) É também discutido se uma cláusula estatutária de preferência tem eficácia real quando isso não foi expressamente estabelecido. Tendo em conta a discussáo existente, parece preferivel seguir o caminho mais cauteloso e fazer constar expressamente da cláusula aquela eficácia real quando a mesma seja pretendida. Essa eficácia real poderá permitir ao titular do direito de preferência fazer-se substituir ao eventual adquirente da quota.

\subsubsection{Impasses}

2.1.4.1. O CSC disponibiliza poucos instrumentos para ultrapassar situações de impasse na vida societária, resultantes, por exemplo, de cada um dos dois sócios (ou grupos de sócios) ter igual poder de voto e persistirem empates nas deliberaçóes da assembleia ou da gerência - sendo embora de realçar o disposto no art. $263 .^{\circ}, 3$, sobre desempate para aprovação das contas. Nalguns casos também, as

\section{Comments}

(a) The legality of article clauses regarding priority has been the subject of debate. This is because, a priori, it ensues from Article 229(5) CSC that the effectiveness of a transfer to the company cannot be dependent on a preemption clause. However, it is possible to draft the clause taking this legislation into account.

(b) Also discussed is whether a preemption clause in articles of association has in rem effects when this was not laid down explicitly. Bearing in mind the ongoing debate, it seems preferable to take the most cautious route and explicitly include such in rem effect in the clause when the intention is such. This will allow the holder of the preemptive right to replace the potential acquirer of the share.

\subsubsection{Deadlocks}

2.1.4.1. The CSC provides few instruments to overcome deadlock situations in corporate life which arise when, for example, each of the two shareholders (or groups of shareholders) have equal voting power, and votes at meetings or by directors are repeatedly tied - although it is worth noting the provisions of Article 263(3) on resolving deadlocks for the approval of accounts. In some cases also, 
maiorias exigidas na lei ou nos estatutos para a tomada de certas deliberações não permitem a adoção de medidas que sejam consideradas importantes para a sociedade.

\subsubsection{Recomenda-se a estipu- laçáo nos estatutos de cláusulas de resoluçáo de impasses, como a de roleta, roleta modificada ou leiláo.}

\section{Comentário}

(a) O CSC não prevê expressamente a possibilidade de inclusão nos estatutos de cláusulas de roleta, roleta modificada ou leilão. Tais cláusulas são úteis para a resolução de situaçôes de impasse nas deliberaçóes dos sócios, pois poderão levar a que alguém saia da sociedade, assim deixando abertos novos caminhos. A compatibilidade das cláusulas com o regime legal deve ser estudada com cuidado.

(b) A utilidade daquelas cláusulas para a resolução de impasses pode ser comprovada através de uma breve referência ao seu conteúdo. Numa cláusula de roleta o sócio que manifesta vontade de adquirir por um certo preço a quota de outro confere a este a possibilidade de aceitar a oferta ou de adquirir a quota do autor da oferta pelo mesmo preço. Assim, o sócio que apre- deliberative majority required by law or by the articles of association to validly deliberate on certain issues may be an obstacle for important company decisions.

\subsubsection{We recommend that deadlock resolution clauses, such as Russian roulette, mod- ified Russian roulette or auc- tion, be stipulated in the arti- cles of association.}

\section{Comments}

(a) The CSC does not expressly provide for the possibility of including Russian roulette, modified Russian roulette or auction clauses in the articles of association. Such clauses are useful for resolving deadlock situations in shareholders' decisions as they may lead to someone leaving the company, thereby opening up new paths. Compatibility of the clauses with existing legislation should be examined carefully.

(b) We can establish how useful these clauses are to resolve deadlocks by briefly outlining their content. In a Russian roulette clause, the shareholder who expresses a desire to acquire another party's share in the business gives him or her the option to accept the offer or to buy out the first party for the same price. As such, the shareholder who makes the initial proposal does not know what 
senta a proposta inicial náo sabe qual será o desfecho do processo a que deu inicio: tanto pode adquirir a quota do destinatário da proposta, como acabar sem a sua quota. Mas isso também o obriga a não apresentar inicialmente um valor baixo para a aquisição, uma vez que pode ser ele o prejudicado se o fizer. A designação da cláusula faz lembrar o arriscado jogo da roleta russa, pois sabe-se como tudo começa, mas náo se sabe como vai acabar.

(c) Na cláusula de roleta modificada o sócio que apresenta a proposta de aquisição da quota de outro confere a este a possibilidade de aceitar a oferta ou, em vez disso, de apresentar uma contraproposta de venda por um preço mais elevado ou de compra por um preço mais elevado, contraproposta essa que faz com que se reinicie todo o processo até que um deles aceite uma proposta do outro.

(d) Na cláusula de leilāo o sócio que apresenta a proposta de aquisição da quota de outro confere a este a possibilidade de aceitar a oferta ou de apresentar uma contraproposta de compra da quota do primeiro por um prę̧o mais elevado, o que faz com que se reinicie todo o processo até que um deles aceite a proposta do outro. Entretanto, o preço foi subindo.

(e) Para além das já referidas cláusulas, também as cláusulas de amortização de quotas (para a ex- the outcome of the started process will be: he or she may either acquire the share in the business owned by the party who receives the proposal or end up without his or her own share. But this also forces the shareholder not to offer a low price for the acquisition in the first place, as her or she may be the one who loses out. The clause is named after the highrisk game of Russian roulette because everyone knows how it all starts but nobody knows how it will end.

(c) In the modified Russian roulette clause, the shareholder who submits the proposal to acquire the other party's share in the business gives the latter the possibility of accepting the offer or, alternatively, making a counterproposal to sell for a higher price or purchase for a higher price, a counterproposal that restarts the entire process until one of them accepts a proposal from the other.

(d) In the auction clause, the shareholder who presents the proposal to acquire the other party's share in the business gives the latter the possibility of accepting the offer or making a counterproposal to purchase the former's share at a higher price, which restarts the entire process until one of them accepts the other's proposal. Meanwhile, the price has been increasing.

(e) In addition to the clauses outlined above, clauses providing for 
tinção da quota) ou, até, de dissolução (da sociedade) podem ser úteis para, eventualmente, evitar males maiores. A identificação precisa das situaçôes que podem gerar a amortização ou a dissolução é especialmente importante, assim como a correta noção das consequências do funcionamento de tais cláusulas.

(f) A inclusão de cláusulas estatutárias que prevejam o recurso à mediação elou arbitragem deve ser igualmente ponderada.

\subsection{Transmissáo por morte}

2.2.1. O CSC permite que os estatutos da sociedade por quotas impeçam a transmissão da quota aos sucessores do falecido ou condicionar a transmissão a certos requisitos (arts. 225..$^{\circ}$ e 227. ${ }^{\circ}$ ). Aquele Código também permite a introdução de cláusulas estatutárias que confiram aos sucessores do sócio falecido o direito de exigir a amortização da quota ou por algum modo condicionar a transmissão à vontade daqueles (arts. $226 .^{\circ}$ e $227 .^{\circ}$ )

2.2.2. Recomenda-se que seja ponderada a utilidade de cláusulas estatutárias que afastem a transmissáo de quotas aos sucessores do falecido ou de cláusulas que sujeitem essa transmissáo a certos requisitos. Aquela ponderaçáo deve ter em redemption of shares (to dissolve the share) or even dissolution (of the company) can also be useful to avoid potentially greater problems. Accurate identification of the situations that may lead to redemption or dissolution is particularly important, along with a proper understanding of the consequences of the operation of such clauses.

(f) Clauses concerning mediation andlor arbitration should also be weighed.

\subsection{Transfers due to death}

2.2.1. The CSC allows the articles of association of PLLC/SQ to prevent the transfer of the deceased's share in the business to their successors or make the transfer conditional on certain requirements (Articles 225 and 227). The same Code also allows clauses to be included in the articles to give the deceased shareholder' successors the right to demand redemption of the share or make the transfer conditional on their consent in some way (Articles 226 and 227).

2.2.2. We recommend that shareholders evaluate the advantages of article clauses that prevent the transfer of shares to the deceased's successors, or clauses that make such a transfer conditional on certain requirements. This evaluation should consid- 
conta, designadamente, $o$ interesse em manter certos equilíbrios na sociedade e em assegurar a verificaçáo de certos aspetos relativamente ao sucessor.

Em qualquer caso, devem ser devidamente avaliadas as consequências da aplicação das cláusulas (por exemplo, quanto à possibilidade de a sociedade adquirir uma quota própria, quanto à existência de sócio ou terceiro interessado em adquirir a quota, quanto aos casos em que dois ou mais sócios estáo interessados em adquirir a quota, quanto à amortizaçáo).

\section{Comentário}

(a) Os termos em que tem lugar a transmissão por morte das participaçóes sociais em sociedades por quotas podem ser decisivos para o futuro daquelas entidades. A transmissão sucessória pode trazer para a sociedade conflitos familiares. A necessidade de dividir o que fica nem sempre conduz às melhores soluçóes. Pode também suceder que os sócios sobreviventes não queiram, por variadas razóes, ter os sucessores do falecido na sociedade.

(b) A Comissão Europeia já por diversas vezes salientou a importância de preparar a transmissáo da empresa nas PMEs. Lembramos a Comunicação de 23 de julho de er, among others, the benefits of maintaining a certain balance in the company and ensuring that certain issues are verified regarding the successors.

In any event, the consequences of operating the clauses should be properly assessed (regarding, for example, the possibility of the company acquiring own shares, a shareholder or third party who may be interested in acquiring the share, the cases in which two or more shareholders are interested in acquiring the share, the redemption itself).

\section{Comments}

(a) The terms under which share transfers due to death occur in PLLC/SQ may be decisive for the future of these companies. Transfer by inheritance can bring family conflicts into the company. The need to divide up the estate does not always lead to the best solutions. It may also be the case that, for any number of reasons, the surviving shareholders do not want the deceased's successors in the company.

(b) The European Commission has repeatedly stressed the importance of preparing for the transfer of businesses in SMEs. It is worth recalling the Communication of 23 
1994 ("sobre a transmissäo de empresas. Açôes a favor das PME»), a Recomendação 94/1069/CE («sobre a transmissäo das pequenas e médias empresas»), a Comunicação da Comissão de 1998 98/C 93/02 ("relativa à transmissão de pequenas e médias empresas") e a Comunicação da Comissão de 2006 ("Realizar o programa comunitário de Lisboa em prol do crescimento e do emprego. Transmissáo de empresas - Continuidade pela renovação»). Esta última, por exemplo, salientava que "[d] e um modo geral, as sociedades de pessoas dissolvem-se com a morte de um sócio, mas é normalmente possivel assegurar a sua continuidade através de um contrato de sociedade adequado[...]" (ponto 2.6.).

(c) O CSC abre a porta a várias soluçôes possiveis para tentar encontrar o melhor caminho perante as circunstâncias de cada sociedade por quotas. No caso de sociedades familiares em particular, são várias as situaçóes que se podem encontrar (p. ex., sociedade constituida antes do casamentoldepois do casamento; só um dos cônjuges era sócio antes do casamentolambos os cônjuges eram sócios antes do casamentolum ou ambos tornaram-se sócios só depois do casamento; a quota é bem comumla quota é bem próprio; etc.). As cláusulas relativas à transmissão por morte deverão ser adaptadas em
July 1994 ('On the transfer of businesses. Actions in favour of SMEs'), Recommendation 94/1069/EC ('on the transfer of small and medium-sized enterprises'), 98/C 93/02 in 1998 ('on the transfer of small and medium-sized enterprises') and the 2006 Communication from the Commission (Implementing the Community Lisbon Programme for Growth and Jobs. Transfer of Businesses - Continuity through a new beginning'). The latter, for instance, emphasised that 'i]n general, partnerships dissolve with the death of one partner but it is generally possible to ensure continuity by an adequately drafted partnership agreement[...]' (point 2.6.).

(c) The CSC opens the door to several possible solutions to try to find the best path in view of the circumstances of each PLLC/SQ. In the case of family companies in particular, several situations may be encountered (e.g. company incorporated before marryinglafter marrying; only one of the spouses was a shareholder before marrying/ both spouses were shareholders before marryinglone or both only became shareholders after marrying; the share is a jointly-held asset/the share is a separately-held asset; etc.). Clauses regarding transfers due to death should be adapted in line with these situations. The above, of course, subject to utilising a will 
função dessas mesmas situaçôes. Isto, naturalmente, sem prejuizo da utilização de um testamento e da realização de eventuais legados. Para já não falar da partilha em vida.

(d) As consequências da aplicação do regime clausulado devem ser antecipadas. A amortização de quotas pode obrigar ao pagamento de contrapartida avultada; a aquisição de quota pressupóe que haja interessados em adquirir.

\section{CONTITULARIDADE DE QUOTA}

3.1. A contitularidade de quota, resultante, por exemplo, de comunhão hereditária ou conjugal ou de compropriedade originada por compra e venda ou partilha, está regulada nos arts. 222. ${ }^{\circ}$ a $224 .^{\circ}$ do CSC, que destacam a figura do representante comum (interlocutor da sociedade).

3.2. É recomendável que os contitulares designem táo cedo quanto possível um representante comum competente e diligente, promotor e cumpridor das deliberaçóes dos contitulares necessárias ou convenientes.

\section{Comentário}

(a) A contitularidade de quotas pode resultar de circunstâncias and making possible bequests, not to mention partition inter vivos.

(d) The consequences of operating the arrangements outlined in the clauses should be considered in advance. Redemption of shares may require the payment of a sizeable consideration; acquisition of shares presupposes that there are parties interested in acquiring them.

\section{JOINT HOLDING OF SHARES}

3.1. Joint holding of shares deriving, for example, from a community of heirs or a marital community or from co-ownership arising from a sale or partition is regulated in Articles 222 to 224 CSC, which highlight the role of the common representative (company interlocutor).

3.2. We recommend that co-owners name a competent and dedicated common representative as soon as possible, to advance and implement any necessary or pertinent decisions made by the co-owners.

\section{Comments}

(a) Joint holding of shares may arise from widely varying circumstances. 
muito diversas. Há contitularidade quando existe comunhão e nos casos em que a quota se encontra em compropriedade. Tanto a comunhão como a compropriedade podem ter surgido por vários motivos. A comunhão pode ser conjugal ou hereditária. A compropriedade pode ter resultado, designadamente, de uma compra e venda ou de uma partilha. Antes da partilha a manutenção de contitularidade também merece atenção, pois foi apontada como causa de algumas dificuldades (nomeadamente no que diz respeito ao exercício dos direitos sociais, à falta de envolvimento dos herdeiros nos assuntos da sociedade, à tentativa de ingerência excessiva ou à eventual paralisação dos órgãos da sociedade).

(b) Quanto aos casos de transmissão por morte, o CSC contém possibilidades que devem ser exploradas para tentar evitar muitas das situaçóes indesejáveis. O mesmo se diga quanto às alternativas que são deixadas para a eventual amortização de quotas, cujo regime pode ser um auxílio em caso de contitularidade. Ou seja: é possivel tentar eliminar ou reduzir as desvantagens resultantes da existência de contitularidade. Lembre-se a possibilidade de estabelecer nos estatutos que, falecendo um sócio, a respetiva quota não se transmitirá aos sucessores do falecido ou que essa transmissáo
Joint holding exists when there is a community and in cases where the share is held in joint ownership. Communities and joint ownership may arise for a number of reasons. Communities may be marital or may be communities of heirs. Joint ownership may derive, among others, from a sale or a partition. Before considering partitions, joint holding arrangements should also be addressed as they were identified as the cause of a number of difficulties (namely with regard to the exercise of social rights, lack of involvement of heirs in the affairs of the company, attempts to interfere excessively or instances where the organs of the company may be brought to a standstill).

(b) With regard to cases of transfer due to death, the CSC outlines possibilities that should be explored to try to avoid many undesirable situations. The same is true for the remaining possible alternatives for the redemption of shares, which presents a legal regime that may be helpful in cases of joint holding. In other words: it is possible to attempt to offset or reduce the disadvantages arising from the existence of a joint ownership arrangement. It should be borne in mind that the articles of association can establish that, if a shareholder dies, the corresponding share shall not be transferred to the deceased's successors or the transfer 
fica sujeita a certos requisitos (art. 225..$^{\circ}$ 1, do CSC).

Parece, assim, também viável afastar a transmissão da quota se dai resultar uma situação de contitularidade. Essa contitularidade pode igualmente ser prevista como fundamento de amortização da quota (arts. 232..$^{\circ} 1$, e 233.,$~ 1$, do CSC): designadamente, quando a contitularidade seja o resultado de partilha de herança ou de liquidação de sociedade que fosse titular da quota.

(c) O CSC procura atenuar as desvantagens resultantes da contitularidade com a imposição do exercício dos direitos inerentes à quota através de representante comum (art. 222. $\left.{ }^{\circ}, 1, C S C\right)$. Mas aqui existe alguma margem para se procurar encontrar uma solução melhor do que a resultante da aplicação do regime legal. Nomeadamente, porque há casos em que o representante comum pode ser designado por disposição testamentária. Quanto ao cabeça-de-casal, também as regras que dizem respeito à sua nomeação devem ser estudadas em função dos interesses dos contitulares. Pense-se, por exemplo, na possibilidade de designação por acordo (art. 2084. ${ }^{\circ}$ do CCiv.), no regime da escusa (art. 2085. ${ }^{\circ}$ do CCiv.) e da remoção (art. 2086. ${ }^{\circ}$ do CCiv.). shall be subject to certain requirements (Article 225(1) CSC).

As such, it also seems feasible to prevent the share transfer if it results in a joint holding situation. Such a joint holding arrangement can also be established as grounds for redemption of the share (Articles 232(1) and 233(1) CSC): specifically, when a joint holding arrangement is the consequence of the partition of an inheritance or the winding-up of the company that owns the share.

(c) The CSC seeks to mitigate the disadvantages arising from joint holding by dictating that the rights pertaining to the share be exercised through a common representative (Article 222(1) CSC). But some scope exists here to improve on the solution provided by applying the law. In particular, because there are cases where the common representative may be appointed by a testamentary disposition. The rules on nominating the administrator of the estate must also be analysed in the light of the joint holder's interests. Consideration should be given, for example, to the possibility of nomination by agreement (Article 2084 CCiv ${ }^{*}$ Civil Code+) and under the rules on exemption (Article 2085 CCiv) and removal (Article 2086 CCiv). 
(d) Assim, as sociedades por quotas devem procurar encontrar atempadamente as soluçóes mais adequadas para a nomeação de um representante comum dos contitulares que reúna as melhores condiçóes possiveis para servir os interesses dos contitulares. Mas isso não basta para reduzir significativamente a possibilidade de existência de problemas. É que o representante comum está obrigado para com os contitulares nos termos do que estes deliberarem de acordo com o art. 224. ${ }^{\circ}, 1$, do CSC. E não pode deixar de ser salientada a importância de os contitulares usarem essa possibilidade de forma a que a atuação do representante comum respeite $o$ que é a vontade daqueles.

\section{ExoneRAÇÃo DE SócIO}

4.1. A exoneração de sócio (a saída da sociedade por iniciativa dele com fundamento em facto previsto na lei ou nos estatutos e com direito a receber o valor de liquidação da quota) está prevista em alguns preceitos da parte geral do CSC e em especial no art. $240 .^{\circ}$.

\subsection{Também porque a saída pela via da cessáo de quotas pode ser muito difícil ou finan-}

(d) As such, PLLC/SQ should endeavour to find the most appropriate solutions in a timely manner to nominate a common representative for the joint holders who is best able to serve the interests of the joint holders. But this is not enough to significantly reduce the possibility that problems may occur. The common representative has an obligation towards the joint holders under the terms decided by them in accordance with Article 224(1) CSC. Furthermore, we should draw attention to the important need for joint holders to make use of this option so that the actions of the common representative respect their wishes.

\section{WithDRAWAL OF SHAREHOLDERS}

4.1. The withdrawal of shareholders (leaving the company on their own initiative, on the basis of a circumstance envisaged by law or the articles of association, and with the right to receive the liquidation value of the share) is provided for in a number of provisions of the general part of the CSC, in particular Article 240.

\subsection{In addition, because the exit by means of share transfer}


ceiramente desajustada, recomenda-se a inclusáo nos estatutos de cláusulas permitindo a exoneraçáo por causas náo previstas na lei - por exemplo, quando um sócio tenha de mudar de residência para local distante da sede social, ou atinja certa idade, ou contraia doença prolongada, ou assuma cargo público.

\section{Comentário}

(a) $O$ direito de exoneração resulta da lei em situaçóes tipificadas (por exemplo: se o estatuto proibir a cessão de quotas, se for deliberado um aumento de capital a subscrever total ou parcialmente por terceiros, se for aprovada a mudança do objeto social, se a sociedade não excluir outro sócio havendo justa causa para o fazer, etc.). Mas também pode ser atribuido pelo contrato de socieda$d e$, desde que respeitados certos limites (art. 240., 1, CSC): são as cláusulas estatutárias de exoneração. Porque exerce um direito a sair da sociedade, o sócio que se exonera não necessita do consentimento da sociedade ou dos outros sócios, nem de encontrar um comprador para a quota - eis uma conveniência desta via quando comparada com a vulgar cessão de quotas. can be very difficult or financially burdensome, we recommend including clauses in the articles of association to permit withdrawal for reasons not envisaged by law - for example, when a shareholder has to change place of residence to a location distant from the registered office, reaches a certain age, suffers a prolonged illness or takes up public office.

\section{Comments}

(a) The right of withdrawal derives from situations defined by law (for example: if the articles of association prohibit the transfer of shares; if a capital increase, subscribed wholly or partly by third parties, is approved; if a decision is adopted to change the company's purpose; if the company does not exclude another shareholder when there is good cause to do so, etc.). But it can also be granted by the articles of association, provided that certain limits are respect-ed (Article 240(1) CSC): the so-called withdrawal clauses. Because they are exercising a right to exit the company, withdrawing shareholders do not require the consent of the company or the other shareholders, and they do not need to find a buyer for the share - this is one of the advantages of this route compared to an ordinary share transfer. 
(b) Contudo, as cláusulas que preveem fundamentos de exoneração não podem ser puramente arbitrárias, isto é, não podem remeter para a simples vontade do sócio de abandonar a sociedade. É necessário que assentem na superveniência de situaçóes ou de factos que justifiquem minimamente essa saida da sociedade, por tornarem (em grau variável) inexigivel ao sócio que nela permaneça.

Podem, ainda assim, abranger situaçóes menos graves do que as tipificadas na lei (por exemplo, podem conferir o direito à exoneração em casos de mudança de residência, ou quando o sócio atinja certa idade, ou assuma cargos públicos). Admitem-se normalmente também cláusulas de exoneração com conteúdo genérico, prevendo que o sócio se possa exonerar por "justa causa" ou "motivo grave" (sobretudo quando completadas com hipóteses exemplificativas).

(c) Convém notar que a saida $d a$ sociedade não é automática: recebida a declaração escrita do sócio que se pretende exonerar, a sociedade tem um prazo de 30 dias para decidir o que fazer à quota: amortizá-la, adquiri-la ou fazê-la adquirir por outro sócio ou por terceiro (art. 240. ${ }^{\circ}, 4$, CSC). Só depois de efetivamente amortizada ou transmitida a quota é que o sócio se considera como tendo deixado a sociedade. (b) However, clauses giving grounds for withdrawal cannot be entirely arbitrary, i.e. they cannot refer to a mere wish of the shareholder to exit the company. They must be based on the existence of situations or circumstances that provide a minimum justification for exiting the company because they render it unsustainable (to a varyable degree) for the shareholder to remain.

They may, however, address less serious situations than those defined by law (for example, they can grant the right of withdrawal in cases of change of residence, or when the shareholder reaches a certain age or takes up public office). It is also usually acceptable to include withdrawal clauses with generic content establishing that the shareholder may withdraw for 'good cause' or on 'serious grounds' (especially when completed by examples).

\section{(c) It should be noted that departure} from the company is not automatic: after receiving a written statement from the shareholder who wishes to withdraw, the company has 30 days to decide what to do with the share: redeem it, acquire it or have another shareholder or third party acquire it (Article 240(4) CSC). The shareholder is only considered to have exited the company after the share is actually redeemed or transferred. 
(d) O legislador preocupou-se em consagrar meios de defesa do sócio perante a inércia da sociedade. Assim, se a sociedade não tomar qualquer medida depois de receber a declaração de exoneração, o sócio pode requerer a dissolução da sociedade por via administrativa (art. 240. ${ }^{\circ}$, 4 CSC). Este meio de defesa está igualmente ao seu dispor caso não receba em devido tempo o valor correspondente à sua quota (art. 240. ${ }^{\circ}$, 6 e 7). Sobre o valor a atribuir à quota, veja-se o n. ${ }^{\circ} 6$ deste Guia.

\section{EXCLUSÃO DE SÓCIO}

5.1. Um sócio pode ser excluído da sociedade por deliberação nos casos especificados na lei ou nos estatutos, e também por decisão judicial (antecedida e seguida de deliberação dos sócios) verificadas certas circunstâncias (em particular, a adoção de certos comportamentos) prejudiciais para a sociedade - arts. $241 .^{\circ}$ e $242 .^{\circ}$ do CSC.

5.2. Para reforço da prevençáo de comportamentos e situaçóes gravemente prejudiciais para a sociedade e para reaçáo mais célere - por deliberaçáo dos sócios, em lugar de ter de recorrer (d) The legislator undertook to establish means of protection for shareholders against inactivity on the part of companies. As such, if the company does not take any action after it receives the statement of withdrawal, the shareholder may request dissolution of the company through administrative channels (Article 240(4) CSC). This means of protection is also at their disposal if they do not receive the amount corresponding to their share in due time (Article 240(6) and (7)). See 6. below on how to assess share value.

\section{EXCLUSION OF SHAREHOLDERS}

5.1. A shareholder may be excluded by a resolution in cases defined by law or the articles of association, or by a judicial decision (preceded and followed by a resolution by the shareholders) after certain circumstances (in particular, certain conducts) that cause detriment to the company are confirmed - Articles 241 and 242 CSC.

5.2. To strengthen the prevention of conducts and situations that cause serious detriment to the company and to facilitate a more agile response - by shareholders' decision - it is 
a tribunal -, recomenda-se que os estatutos estabeleçam causas de exclusáo respeitantes ao comportamento de sócios (por exemplo, aproveitamento indevido de oportunidades de negócios da sociedade, concorrência desleal, apropriaçáo ilícita de bens sociais, propositura frequente de açóes chicaneiras contra a sociedade) ou a certas situaçóes em que eles incorram (por exemplo, acompanhamento de maior ou insolvência declarados judicialmente).

\section{Comentário}

(a) $O$ direito de a sociedade excluir um sócio pode decorrer da lei-por exemplo, em caso de náo cumprimento da obrigação de entrada; por utilização indevida de informaçōes societárias; ou quando o sócio adote um comportamento desleal ou gravemente perturbador do funcionamento da sociedade, o qual tenha causado ou possa vir a causar a esta prejuizos relevantes. Mas pode também ser atribuido por cláusula estatutária (art. 241. , 1, CSC).

(b) Se é certo que a previsão legal do art. 242. ${ }^{\circ}$ CSC permite excluir um sócio em boa parte das situaçóes em que a presença deste na sociedade se tornou insustentável, a verdade é que a sua concretização exige o recurso ao tribunal, a quem recommended that the articles of association establish exclusion causes with regard to the conduct of share- holders (for example, improper use of the company's business opportunities, unfair competition, misappropriation of company assets, frequent duplicitous lawsuits against the company) or certain situations in which they are involved (for example, insolvency declared by a court).

\section{Comments}

(a) The company's right to exclude a shareholder may derive from law-for example, in the event of non-compliance with the obligation to make a capital contribution; for improper use of company information; or conduct by the shareholder that is unfair or severely disruptive to the operation of the company, which has caused or may cause it significant losses. But it can also be granted by a clause in the articles of association (Article 241(1) CSC).

(b) While it is the case that the content of Article 242 CSC authorises the exclusion of shareholders in many situations in which their presence in the company has become unsustainable, the truth is that implementation of this provision requires 
cabe apreciar os factos e decretar, se assim o entender, a exclusão. Já a previsão estatutária dispensa a intervenção do tribunal: a exclusão dá -se por deliberação da sociedade com base no fundamento previsto no pacto (art. 246. ${ }^{\circ}, 1$, al. c), CSC) - sem embargo, claro, de o sócio excluido poder posteriormente recorrer à via judicial para contestar a deliberação que o afastou.

Por isso se recomenda que seja ponderada a inclusáo de cláusulas de exclusão nos estatutos da sociedade, dada a sua conveniência para evitar a eclosáo ou o arrastamento de conflitos entre os sócios e a sociedade.

(c) Todavia, as cláusulas que preveem fundamentos de exclusão não podem ser discricionárias: desde logo, não é admissivel uma exclusão por simples deliberação maioritária, sem qualquer motivo justificativo. As cláusulas estatutárias de exclusão devem espelhar comportamentos e situaçóes relativos ao sócio que, por acarretarem prejuizos para a sociedade (atuais ou potenciais), tornem inexigivel a esta que continue a suportar a presença do sócio. Os factos que fundamentam a exclusão devem ainda ser suficientemente especificados e determinados, para poderem funcionar como horizonte de previsibilidade para atuaçóes futuras dos sócios. recourse to a court which is responsible for evaluating the events and, if appropriate, ordering the exclusion. In constrast, the provisions of the articles of association remove the need for preliminary intervention by the courts: exclusion is triggered by a company decision based on the grounds established in the articles of association (Article 246(1)(c) CSC) - however, excluded shareholders may of course apply to the courts at a later date to challenge the decision that excluded them.

As such, it is advisable to consider adding exclusion clauses to the company's articles of association as they may help prevent conflicts between shareholders and the company from arising or dragging on.

(c) However, clauses establishing grounds for exclusion cannot be discretionary: an exclusion cannot be implemented by a decision adopted by a sheer majority without any proper justification. Exclusion clauses in the articles of association must reflect conducts and situations with regard to the shareholder which, by causing the company (current or potential) losses, make it unsustainable for the company to continue tolerating the presence of the shareholder. The circumstances that justify exclusion must also be sufficiently specified and identified to be able to act as a horizon of predictability for future actions by the shareholders. 
(d) Além de facilitar o exercício do direito de exclusão pela sociedade, $o$ elenco de causas que venha a constar do estatuto pode funcionar como um alerta para os sócios quanto aos concretos comportamentos prejudiciais que devem evitar, sob pena de exclusão. Um exemplo relevante é oferecido pela concorrência que o sócio venha a fazer à sociedade (nas sociedades por quotas, só os gerentes estão obrigados a abster-se de concorrer com a sociedade, náo havendo norma legal que proíba os simples sócios de o fazer).

(e) A saida do sócio da sociedade implicará o recebimento de uma contrapartida, normal mas não necessariamente correspondente ao valor da quota: pode ser menor (arts. 241. ${ }^{\circ}, 3$ e 242. ${ }^{\circ}, 4$ CSC). A quota do sócio excluido será amortizada ou adquirida pela sociedade, por outro sócio ou por terceiro (arts. 241. ${ }^{\circ}, 2$ e 242. ${ }^{\circ}, 3$ CSC). Sobre o valor a atribuir à quota, veja-se o n. ${ }^{\circ} 6$ deste Guia.

\section{VALORES dE LIQUIDAÇÃO DAS QUOTAS}

6.1. Resulta de várias normas do CSC, incluindo as respeitantes à exoneração e à exclusão de sócios (arts. 240. ${ }^{\circ}, 5,241 .^{\circ}, 2,242 .^{\circ}$, 4 ), o princípio geral da identifi- (d) In addition to allowing the company to exercise the right of exclusion, the causes listed in the articles of association can act as an admonition to shareholders regarding specific detrimental conducts that must be avoided, under penalty of exclusion. A relevant example is shareholders engaging in competition against the company (in PLLC/SQ, only directors are obliged to refrain from competing with the company; there is no law prohibiting ordinary shareholders from doing so).

(e) A shareholder's departure from the company will entail receiving compensation, usually but not necessarily corresponding to the value of the share: it may be a lower amount (Articles 241(3) and 242(4) CSC). The excluded shareholder's share will be redeemed or acquired by the company, by another shareholder or by a third party (Articles 241(2) and 242 (3) CSC). See 6. below on how to assess share value.

\section{SHARE LIQUIDATION VALUES}

6.1. A number of provisions of the CSC, including those regarding the withdrawal and exclusion of shareholders (Articles 240(5), 241(2) and 242(4)) give rise to 
cação do valor de liquidação das quotas com o valor real ou pleno das mesmas: valor proporcional ao pleno valor das sociedades respetivas calculado com referência a certo momento segundo método económico-financeiro adequado. Todavia, com um ou outro limite, essas normas admitem que os estatutos estipulem critérios de avaliação diferentes.

\subsection{Para prevenir dificuldades} e litígios na avaliaçáo de quotas, é recomendável que os estatutos estipulem critérios simples de fixaçáo dos valores de liquidaçáo, por exemplo o valor resultante do último balanço aprovado ou o valor nominal das quotas, eventualmente com fatores de correçáo para os casos de manifesta desproporçáo entre o valor real e o que se alcança por aqueles critérios.

\section{Comentário}

(a) O art. 105., 3, CSC permite que os interessados náo satisfeitos com a avaliação da sociedade requeiram uma segunda avaliação, desta feita judicial, da contrapartida devida pela quota. Para isso deveráo recorrer ao processo especial de liquidação de participaçóes the general principle of equating the liquidation value of shares with their real or full value: a value proportional to the full value of the corresponding companies calculated in reference to a specific point in time in accordance with the appropriate financial and economic method. However, with some restrictions, these rules allow the articles of association to stipulate different evaluation criteria.

\subsection{To avoid difficulties and dis-} putes in the evaluation of shares, we recommend that the articles of association set out simple criteria for establishing liquidation values, for example the value derived from the most recently adopted balance sheet or the nominal value of the shares, with correction factors where necessary if there is a manifest disproportion between the real value and the value calculated using such criteria.

\section{Comments}

(a) Article 105(3) CSC allows interested parties who are not satisfied with the company's evaluation to request a second, judicial, evaluation of the compensation payable for the share. To do this, they should follow the special procedure for the liquidation of shares established 
sociais previsto nos arts. $1068 .^{\circ} \mathrm{e}$ 1069. ${ }^{\circ}$ CPCiv., obtendo a determinação pelo tribunal do valor da participação social num dado momento temporal e com base no critério já referido (estado da sociedade).

(b) Os já mencionados regimes da exoneração e da exclusão de sócio permitem que o valor recebido pelo sócio seja diferente do que resulta do critério legal, se houver previsão estatutária nesse sentido. Deve assim ponderar-se a conveniência de fazer uso desta faculdade de definir estatutariamente o valor a satisfazer ao sócio exonerado ou excluido.

(c) No âmbito da exoneração fundada em cláusula estatutária, pode o pacto social fixar um valor diferente, eventualmente mais baixo, embora não possa privar completamente o sócio de uma contrapartida. Já nas hipóteses de exoneração com base em fundamento legal, as previsóes estatutárias relativas à contrapartida não podem, direta ou indiretamente, conduzir ao pagamento ao sócio de valor inferior ao que resultaria do critério legal (art. 240., 8 CSC).

(d) No âmbito da exclusão, a lei permite a modelação estatutária com maior amplitude: tenha a exclusão base legal ou contratual, o in Articles 1068 and 1069 Code of Civil Procedure to obtain the court's determination of the share value at a specific point based on the aforementioned criterion (state of the company).

(b) The aforementioned rules for the withdrawal and exclusion of shareholders allow the amount received by the shareholder to be different from that derived from the legal criterion, if there is a provision in the articles of association to that effect. As such, it is worth considering the advantages of using this power to define the amount payable to a withdrawing or excluded shareholder in the articles of association.

(c) With regard to withdrawals supported by a clause in the articles of association, this document may establish a different, possibly lower, value, although it cannot completely deny compensation to the shareholder. In the event, however, of withdrawal on a legal basis, the provisions of the articles of association regarding compensation cannot result, directly or indirectly, in the shareholder being paid an amount lower than that derived from the legal criterion (Article 240(8) CSC).

(d) With regard to exclusions, the law allows articles of association to be drafted more broadly: if the exclusion has a legal or contractual 
pacto social pode fixar um valor ou um critério diferente do legal - frequentemente, um valor mais baixo que o legal. Muito comum é a previsão estatutária do pagamento do valor nominal da quota (normalmente mais baixo que o valor de liquidação). O controle de eventuais excessos nesta faculdade de modelação passará pelo crivo geral do art. 812. ${ }^{\circ}$ do CCiv., o que pode conduzir ao aumento do concreto valor a receber pelo sócio.

\section{Conselho consultivo}

7.1. O CSC não prevê este órgão (órgãos necessários são apenas o(s) sócio(s) e a gerência). Mas náo impede que os estatutos o prevejam - desde que a respetiva competência náo colida com a dos órgãos necessários ou com a do órgão legal-facultativo (conselho fiscal ou fiscal único).

\subsection{Em algumas sociedades,} especialmente familiares, é recomendável a constituiçáo de um conselho consultivo composto por sócios e náo sócios para aproveitamento do saber e experiência dos sócios mais antigos e para a integraçáo progressiva de sócios mais novos e basis, the articles may set a different value or criterion to the one established by law - usually a lower value than the one established by law. A provision establishing payment of the nominal value of the share (usually lower than the liquidation value) is very common. Any possible excesses in the drafting of these criteria will be subject to the controling standards outlined in Article 812 CCiv, which may lead to an increase in the specific amount received by the shareholder.

\section{ADVISORY BOARD}

7.1. The CSC makes no provision for this organ (the only organs necessary are the shareholder(s) and the board of directors). However, it does not preclude the articles of association from providing for it - as long as the corresponding powers do not enter in conflict with those of the necessary organs or those of the optional legal organ (supervisory board or statutory auditor).

7.2. In some companies, especially family enterprises, it is recommendable to set up an advisory board formed of shareholders and non-shareholders to draw on the knowledge and ex- 


\section{de futuros sócios na vida da so- ciedade.}

perience of older shareholders, and to progressively incorporate younger and future shareholders into the life of the company.

\section{Comentário}

O CSC não prevê a possibilidade de incluir nos estatutos da sociedade a constituição de um órgáo consultivo, mas não parece de afastar a legalidade dessa solução. É, porém, necessário que tal órgão não ponha em causa as competências imperativas dos órgãos legalmente previstos.

Como se lê na Comunicação da Comissão de 2006 acima referida, os "fundadores de uma empresa procrastinam, por vezes, a preparação da transmissáo, receando que a passagem do testemunho prejudique o seu estatuto social e o seu papel no seio da família". Nas sociedades por quotas familiares o conselho consultivo poderia ser o órgão em que os membros da familia que se retiravam de um papel mais ativo (desde logo como gerentes) ainda teriam uma palavra a dizer. Uma posição no conselho consultivo poderia servir para convencer algum sócio a reduzir o seu poder na sociedade em troca de um "lugar de recuo».

Se existir um protocolo familiar que preveja a criação de um conselho de família, é necessário que as duas realidades sejam articula-

\section{Comments}

The CSC does not envisage the possibility of including the formation of an advisory body in the articles of association, but it does not appear to deny the legality of this solution. However, such an organ must not jeopardise the mandatory powers of organs constituted pursuant to law.

As the aforementioned 2006 Communication from the Commission indicates, business founders sometimes procrastinate with their transfer planning for fear that giving up the control of the business will impair their social status and their role in their family' (2.2.). In family-owned limited companies, the advisory board may be an organ where family members who have withdrawn from a more active role (primarily as directors) can continue to have a voice. A position on the advisory board could be used to convince a shareholder to relinquish some of their power in the company in exchange for a 'place of refuge'.

If there is a family agreement establishing the creation of a family council, the two bodies must 
das para evitar conflitos. Os pactos be coordinated to avoid conflicts. familiares (e os pactos empresa- Family pacts (and business agreeriais em geral) foram reconhecidos ments in general) were recognised na Comunicação da Comissão de in the 1998 Communication from 1998 "relativa à transmissäo de the Commission 'on the transfer of pequenas e médias empresas" como small and medium-sized enterprisinstrumentos que podem reforçar a es' as instruments that can increase continuidade da empresa. the continuity of businesses. 



\section{III - DA GERÊNCIA}

\section{CoMPOSIÇÃo}

1.1. A gerência é composta por uma ou mais pessoas singulares com capacidade jurídica plena, sócias e/ou não sócias (CSC, art. $\left.252 .^{\circ}, 1\right)$.

1.2. Tendo em conta a dimensão e complexidade da empresa da sociedade e a competência e disponibilidade do(s) sócio(s), recomenda-se a integraçáo na gerência de um ou mais gestores profissionais náo sócios.

\section{Comentário}

(a) Frequentemente, todos os sócios são designados gerentes nos estatutos. Mesmo quando se sabe à partida que alguns deles (com outras profissóes) não vão exercer, de facto, a gerência (apesar de às vezes serem remunerados enquanto gerentes). O que, além de disfuncional, pode acarretar consequências inesperadas em matéria de responsabilidade: alguém que aceita ser gerente

\section{III - BOARD OF DIRECTORS}

\section{Composition}

1.1. The board of directors is formed of one or more natural persons with full legal capacity, shareholders and/or non- shareholders (Article 252(1) CSC).

\subsection{Taking into account the size and complexity of the company business, and the capacity and availability of the sharehold- er(s), we recommend including one or more professional man- agers who are not shareholders on the board of directors.}

\section{Comments}

(a) Frequently all the shareholders are appointed as directors by the articles of association, even when it is acknowledged from the outset that some of them (who have other professions) will not, in fact, act as directors (although they are sometimes paid as directors). This, in addition to being dysfunctional, may have unexpected consequences regarding liability: anyone who agrees to be a di- 
(ainda que não executivo) tem deveres cujo incumprimento pode levar à responsabilização (civil, tributária).

(b) Os sócios só devem ser designados gerentes quando tenham competência e disponibilidade para exercer $o$ cargo. E se a sociedade tiver capacidade financeira e exigir saberes não possuídos por sócios, deve um ou mais não-sócios ser eleitos gerentes. Especialmente nas sociedades familiares, os gerentes não sócios facilitam a mediação nos conflitos entre interesses familiares e empresariais, e a não confusão do património da sociedade com o da família.

\section{DESIGNAÇÃO E DESTITUIÇÃO DOS GERENTES}

2.1. Os gerentes são designados no ato constituinte da sociedade (contrato ou negócio jurídico unilateral) ou, posteriormente, por decisão do(s) sócio(s) (deliberação dos sócios ou decisão do sócio único) - são estes os modos principais de designação (CSC, arts. 252. ${ }^{\circ}, 2$, 270. $\left.{ }^{\circ}-\mathrm{E}, 1\right)$.

A designação dos gerentes é feita por tempo indeterminado, salvo se os estatutos da sociedade ou $\mathrm{o}$ ato de designação fixarem um prazo (CSC, art. 256. ${ }^{\circ}$ ). rector (even in a non-executive role) has duties and a failure to fulfil these may lead to (civil or tax) liability.

(b) Shareholders should only be appointed as directors when they have the necessary ability and availability to carry out their obligations. Moreover, if the company has the financial capacity and requires expertise that the shareholders do not possess, one or more non-shareholders should be named as directors. In family companies in particular, non-shareholder directors may enable mediation in conflicts between family and business interests and clarity regarding the distinction between the company's assets and those of the family.

\section{APPOINTING AND REMOVING DIRECTORS}

2.1. Directors are appointed in the act of incorporation of the company (contract or unilateral act) or, subsequently, by a decision adopted by the shareholder(s) (resolution of shareholders or decision of the sole shareholder) - these are the main methods of appointment (Articles 252(2) and 270-E(1) CSC).

Directors are appointed for an indefinite period, unless the company's articles of association or the instrument of appointment 
Em regra, a destituição dos gerentes por decisão do(s) sócio(s) é livre: pode ser feita a todo o tempo, haja ou não justa causa (CSC, art. 257. $\left.{ }^{\circ}, 1\right)$.

\subsection{Para promover políticas} de segurança jurídica e de reconhecimento do mérito, recomenda-se que os estatutos estabeleçam a designaçáo por prazo certo (sem prejuízo de possíveis reeleiçóes) e a destituiçáo só com justa causa. establish a term of office (Article 256 CSC).

As a rule, no restrictions apply to the removal of directors by decision of the shareholder(s): it can be effected at any time, with or without good cause (Article 257(1) CSC).

2.2. To promote policies that provide legal certainty and recognise achievement, we recommend that the articles of association establish that directors shall be appointed for a set term (subject to possible re-election) and may only be removed with good cause.

\section{Comments}

(a) A rule that appoints directors for an indefinite period may lead to the non-replacement of individuals who are not (or no longer) suited to running the company. There is also a concern that a possible removal may be found to be without good cause and the company may subsequently be obliged to compensate the director who was removed (see art. 257.'(7) CSC: "If no compensation has been agreed by contract, the director that has been removed without good cause has the right to be compensated for damages, but it must be assumed that he would not be kept in charge for more than four years or for the time needed 
(b) Em contrapartida, a exigência estatutária de justa causa (designadamente o incumprimento, ou a impossibilidade de cumprimento, de deveres fundamentais dos gerentes) para a destituição deliberada pelos sócios contraria a prática (não infrequente) de arbitrariedades e nepotismos das maiorias. Note-se que essa exigência estatutária não significa atribuir aos gerentes-sócios um direito especial à gerência, que só poderia ser extinto com o acordo do sócio-gerente ou por decisáo judicial de destituição com justa causa.

\section{REMUNERAÇÃo dOS GERENTES}

3.1. A fixação das remunerações dos gerentes compete aos sócios deliberação dos sócios ou decisão do sócio único (CSC, art. 255. ${ }^{\circ}$, 1, 277. o-E, 1); é nula a fixação efetuada por outro órgáo ou por terceiro. Só com autorização dos estatutos da sociedade pode a remuneração de um gerente consistir, total ou parcialmente, em participaçáo nos lucros sociais (CSC, art. 255. ${ }^{\circ}, 3$ ). to end the period for which he has been appointed").

(b) In contrast, a stipulation in the articles of association requiring good cause (specifically, the failure to comply, or the impossibility of complying, with the basic duties of directors) for a removal decided by the shareholders counters the (not infrequent) practice of arbitrariness and nepotism on the part of majorities. It should be noted that this requirement in the articles does not entail granting shareholder directors a special right to sit on the board of directors, which could only be revoked with the consent of the shareholder director or by a judicial decision to remove them with good cause.

\section{REMUNERATION OF DIRECTORS}

3.1. It is the responsibility of the shareholders to set the remuneration for directors - resolution of shareholders or decision of the sole shareholder (Article 255(1) and 277-E (1) CSC); the setting of remuneration by another body or by a third party is null and void. The director's remuneration can only consist, totally or partially, of a share in company profits if this is authorised by the company's articles of association (Article 255(3) CSC). 
3.2. Recomenda-se que a fixaçáo da remuneraçáo de cada gerente seja feita anualmente, com discriminaçáo do montante em dinheiro e das eventuais componentes náo monetárias. Recomenda-se também que as "gratificaçóes» aos gerentes sejam concedidas somente quando os estatutos da sociedade as autorizem.

\section{Comentário}

(a) É importante para todos, sócios e gerentes, saber exatamente o que e quanto tem a sociedade depagar aos gerentes. Além de uma importância em dinheiro, pode a remuneração compreender componentes não monetárias, como, por exemplo, a utilização de viatura da sociedade e limite máximo do combustivel a ela afeta, prémios de gestão, seguros pessoais cujos prémios são pagos pela sociedade.

(b) Deve a remuneração dos gerentes ser fixada de acordo com a qualidade e quantidade do trabalho de gestão e a situação económica da sociedade. Também porque umas e outra podem variar com o tempo, parece razoável a anualidade para a fixação da remuneração - sem prejuizo de, durante o ano, circunstâncias excecionais justificarem a diminuição da retribuição, por
3.2. It is recommended that each director's remuneration be set annually, with a breakdown of the amount of money and any non-monetary components. It is also recommended that 'bonuses' be granted to directors solely if they are authorised by the articles of association.

\section{Comments}

(a) It is important for everyone, shareholders and directors, to know exactly what and how much the company has to pay directors. In addition to a sum of money, the remuneration may comprise non-monetary components, such as, use of a company vehicle and a fuel consumption limit, management bonuses, personal insurance with premiums paid by the company.

(b) Remuneration for directors should be set in accordance with the quality and quantity of the management work undertaken and the company's financial situation. In addition, because these factors may vary over time, it seems reasonable to set the remuneration on an annual basis - subject to exceptional circumstances that may justify reducing the remuneration during the year, by agreement between the 
acordo entre a sociedade e o gerente, ou por decisáo judicial requerida pela sociedade (cfr., quanto a esta, o n. 2 do art. 255. ${ }^{\circ}$ do CSC).

(c) Sucede com alguma frequência deliberar-se nas assembleias gerais anuais a atribuição de "gratificaçöes» aos gerentes pelo trabalho exercido. Mas é muito duvidosa a licitude de tal prática quando não existe qualquer base estatutária para a concessão das "gratificaçóes (cfr. no CSC, além do art. 255. ${ }^{\circ}$, 3, os arts. 6. ${ }^{\circ}, 1$ e 2 , e 58. ${ }^{\circ}, 1$, a)).

\section{DeVERES dos GeRENTES}

4.1. Além de específicos deveres legais (determinados na legislação societária e não societária) e estatutários, os gerentes têm ainda os deveres legais gerais de cuidado e de lealdade para com a sociedade previstos no art. $64 .^{\circ}, 1$, do CSC.

Se a sociedade cair em uma situação de probabilidade de insolvência, devem os gerentes tomar medidas para evitar a insolvência (art. 19. ${ }^{\circ}$, b), da Diretiva (UE) 2019/1023, de 20 de junho de 2019, ainda não transposta).

\subsection{Recomenda-se que os ge- rentes de uma sociedade que entre em situação económica difícil ou de insolvência imi-}

company and the director or by a judicial decision sought by the company (in this regard, cf. Article 255(2) CSC).

(c) The allocation of 'bonuses' to directors for work performed is decided at annual general meetings with some degree of frequency. But the legality of this practice is highly questionable if there is no basis in the articles of association for the granting of 'bonuses' (see Article 255(3) CSC, in addition to Articles 6(1) and (2) and 58(1)(a) CSC).

\section{DUTIES OF DIRECTORS}

4.1. In addition to specific statutory duties (laid down by corporate and non-corporate law) and those established by the articles of association, directors also have the general legal duties of care and loyalty towards the company set out in Article 64(1) CSC.

If the company faces the likelihood of insolvency, directors must take steps to avoid insolvency (Article 19(b) of Directive (EU) 2019/1023 of 20 June 2019, yet to be transposed).

4.2. It is recommended that the directors of a company that runs into a situation of economic difficulty or imminent 
nente cumpram os deveres de cuidado e de lealdade sem descurarem os direitos e interesses dos credores sociais.

Se a insolvência for inevitável, náo devem os gerentes continuar a atividade da sociedade sem pedir a declaraçáo judicial de insolvência.

Se for possível a recuperaçáo da empresa da sociedade, os gerentes, independentemente de possíveis deliberaçóes dos sócios, devem adotar medidas que evitem a insolvência - por exemplo, estabelecer negociaçóes com os credores, iniciar um PER (Processo Especial de Revitalizaçáo) ou um RERE (Regime Extrajudicial de Recuperação de Empresas).

\section{Comentário}

(a) Com maior ou menor amparo do direito positivo atual, os gerentes tendem a administrar a sociedade guiados só pelos interesses dos sócios. $\mathrm{Ou}$, às vezes, ilicitamente, a administrar guiados pelos seus interesses particulares.

Estas tendências revelam-se desajustadas para os credores sociais - que têm direitos - especialmente quando a sociedade cai em situação crítica ou pré-insolvencial. Não raramente, os gerentes (e sócios não insolvency should perform their duties of care and loyalty without disregarding the rights and interests of the company's creditors.

If insolvency is unavoidable, the directors should not continue the activity of the company without requesting a judicial declaration of insolvency.

If the company can be recovered, the directors, notwithstanding possible decisions by the shareholders, should take steps to avoid insolvency - for example, hold negotiations with creditors, initiate a PER *Special Revitalisation Procedure or an RERE *Extra-Judicial Business Recovery Scheme.

\section{Comments}

(a) Directors have a tendency to manage companies guided by the interests of shareholders, under the protection, to a greater or lesser extent, of current positive law. Or sometimes, unlawfully, to manage them guided by their own private interests.

These tendencies are not appropriate for the company's creditors who have rights - especially when the company is facing a critical or pre-insolvency situation. Not infre- 
gerentes) promovem, por vias legais ou por vias irregulares, a extinçāo da sociedade e continuam atividade idêntica em outra sociedade (nova, muitas vezes); e os credores, que poderiam não perder, ou perder menos, com a recuperação da empresa social (recuperável), ficam suportando o grosso dos riscos societários.

(b) Mesmo antes de eventuais contra-tendências promovidas por lei (além da já existente, por exemplo a relativa à insolvência culposa), convém lembrar que a tutela dos credores passa normalmente pela recuperação da empresa social recuperável.

\section{Negócios ENTRE A SOCIEDADE E PARTES RELACIONADAS}

5.1. Os negócios celebrados entre o sócio único e a sociedade (unipessoal) estáo sujeitos a vários requisitos (de conteúdo, de forma e formalidades) cujo desrespeito pode acarretar invalidade e a responsabilização do sócio (CSC, art. $\left.2700^{\circ}-\mathrm{F}\right)$.

5.2. Na falta de disposição específica para as sociedades pluripessoais, recomenda-se que os quently, directors (and non-director shareholders) advance the dissolution of the company, by lawful or unlawful means, and continue the same activity in another (often new) company; and the creditors, who could avoid, or suffer fewer, losses if the (recoverable) social enterprise is recovered, are left to bear the bulk of the company's risks.

(b) Ahead of any future counter-tendencies that may be encouraged by law (in addition to those that already exist, such as that regarding culpable insolvency), it should be remembered that the protection of creditors normally requires recovery of the recoverable corporate enterprise.

\section{Transactions betweEn THE COMPANY AND RELATED PARTIES}

5.1. Transactions concluded between the sole shareholder and the (one-person) company are subject to a number of (content, formal and formalities) requirements which, if not complied with, may result in invalidity and liability for the shareholder (Article 270-F CSC).

5.2. In the absence of a specific provision for companies with 
negócios entre a sociedade e um sócio (ou uma pessoa interposta), salvo quando realizados no âmbito da atividade corrente da sociedade e em condiçóes normais de mercado, sejam autorizados por deliberaçáo da gerência; no caso de o sócio ser o gerente único, a autorização deve ser dada por deliberaçáo dos sócios.

Recomenda-se também, relativamente aos negócios entre a sociedade e um gerente (ou pessoa interposta) - tendo em vista o art. 397. ${ }^{\circ}$ do CSC (aplicável por analogia): a náo concessáo de empréstimos ou créditos ao gerente, sob pena de nulidade; a autorizaçáo por deliberaçáo da gerência ou, se esta for unipessoal, por deliberaçáo dos sócios, e o parecer favorável do órgáo de fiscalizaçáo (se existir) para os demais negócios (também sob pena de nulidade), excetuados os negócios compreendidos na atividade corrente da sociedade e celebrados em condiçóes normais de mercado.

\section{Comentário}

(a) Os negócios entre a sociedade (representada por um ou mais ge- more than one shareholder, we recommend that transactions between the company and a shareholder (or an intermediary), except when conducted in the course of the company's ongoing operations and under normal market conditions, be authorised by decision of the board of directors; if the shareholder is the sole director, authorisation should be granted by decision of the shareholders.

As regards transactions between the company and a director (or intermediary), it is also advisable - in view of Article 397 of the CSC (applicable by analogy): not to grant loans or credits to directors, subject to be null and void; to provide authorisation by decision of the board of directors or, for companies with a sole director, by decision of the shareholders and assent of the supervisory body (if applicable) for all other transactions (also otherwise null and void), except for transactions that form part of the ongoing operations of the company and are conducted under normal market conditions.

\section{Comments}

(a) Transactions between the company (represented by one or more 
rentes) e um ou mais sócios (especialmente sócios de controlo) ou um ou mais gerentes apresentam em geral o perigo de danos para a sociedade em consequência da concessáo de vantagens particulares àquelas contrapartes. As "pessoas interpostas" são, principalmente, os cônjuges, os ascendentes e descendentes dos sócios ou dos gerentes e as sociedades controladas por qualquer um desses sujeitos.

(b) Para prevenir ou diminuir o perigo referido, as recomendaçóes promovem a transparência e o controlo coletivo, realçando a necessidade de deliberaçóes sociais para a aprovação de negócios não compreendidos na atividade corrente da sociedade e não efetuados em condiçóes normais de mercado. directors) and one or more shareholders (especially controlling shareholders) or one or more directors generally pose a risk of damage to the company caused by granting special advantages to the counterparties. 'Intermediaries' are, primarily, spouses or relatives in the ascending and descending line of shareholders or directors and companies controlled by any of these individuals.

(b) To prevent or reduce the aforementioned risk, our recommendations encourage transparency and collective control, and emphasise the need for company decisions to approve transactions that do not form part of the ongoing operations of the company and are not conducted under normal market conditions. 
